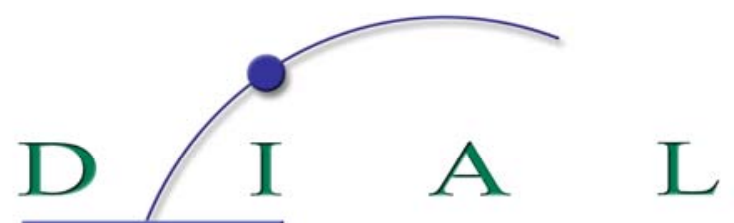

Développement Institutions \& Analyses de Long terme

DOCUMENT DE TRAVAIL

DT/2008-11

\title{
Elections and Economic Policy in Developing Countries
}

Lisa CHAUVET

Paul COLLIER

DIAL・ 4, rue d’Enghien • 75010 Paris • Téléphone (33) 0153241450 • Fax (33) 0153241451 E-mail : dial@dial.prd.fr • Site : www.dial.prd.fr

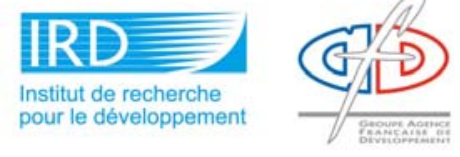




\title{
ELECTIONS AND ECONOMIC POLICY IN DEVELOPING COUNTRIES ${ }^{1}$
}

\author{
Lisa Chauvet \\ IRD-DIAL, Paris \\ chauvet@dial.prd.fr \\ Paul Collier \\ CSAE, Department of Economics, \\ University of Oxford \\ paul.collier@economics.ox.ac.uk
}

Document de travail DIAL

Décembre 2008

\begin{abstract}
This paper explores the impact of elections on economic policies and governance in developing countries. We distinguish between a structural effect, which increases accountability, and a cyclical effect which may be disruptive. Since the effects are offsetting, neither can be analyzed in isolation. We implement an econometric analysis on more than 80 developing countries using positive changes in the Country Policy and Institutional Assessment of the World Bank and the International Country Risk Guide as signaling improvements in economic policy and governance. We find that both structural and cyclical effects matter. The cyclical effect suggests that mid-term is the best moment for policy change. We investigate the structural effect by comparing different frequencies of elections. Except at the extremes, a higher frequency of elections improves both policy and governance net of any cyclical effect. The important exception to this benign net effect is if the electoral process is badly conducted. Badly conducted elections have no structural efficacy for policy improvement. A reasonable interpretation of our results is that honest elections increase accountability and thereby discipline governments to improve economic policy and governance, but that if candidates can win by fraud this chain is broken.
\end{abstract}

Keywords: Elections, economic policy, developing countries

\section{RESUME}

Cet article analyse l'influence des élections sur les politiques économiques et la gouvernance dans les pays en développement. Nous distinguons un effet structurel des élections - via la responsabilité politique d'un effet cyclique potentiellement perturbateur. Puisque ces deux effets se compensent, ils ne peuvent être considérés séparément. Nous menons une analyse économétrique sur un échantillon de 80 pays en développement pour identifier l'impact des élections sur l'amélioration des politiques économiques. Nous utilisons les changements positifs du Country Policy and Institutional Assessment de la Banque mondiale et de l'International Country Risk Guide pour saisir les améliorations des politiques économiques et de la gouvernance. Nous trouvons que l'effet structurel et l'effet cyclique des élections sont tous deux importants. L'effet cyclique des élections suggère que les améliorations de politiques économiques sont plus probables à mi-mandat. Nous utilisons la fréquence des élections pour saisir leur effet structurel. Il semble que des élections fréquentes améliorent la qualité des politiques économiques et de la gouvernance, une fois pris en compte leur effet cyclique. Une exception importante à cet effet structurel positif concerne les élections dont le processus est mal mené : elles n’ont dans ce cas pas d'effet structurel positif. Il semble donc que des élections honnêtes augmentent la responsabilité politique des gouvernements et les incitent ainsi à améliorer les politiques économiques et la gouvernance ; mais si le candidat peut gagner par fraude, cette chaine est rompue.

Mots clés : Elections, politique économique, pays en développement

JEL code: E32; O11; P16

\footnotetext{
${ }^{1}$ Paper presented at the $48^{\text {th }}$ Economic Policy Panel Meeting, October 2008, Paris.
} 


\section{INTRODUCTION}

This paper investigates whether elections in developing countries have improved economic policies and economic governance. Both casual empiricism and casual theorizing suggest that they have done so. As contested elections have become more common since the 1990s, the policy ratings from the World Bank and the International Country Risk Guide have both improved markedly. These improvements accord with the fundamental notion that elections discipline governments into good performance.

Yet this view from on high often collides with the actual experience of individual elections. The Kenyan election of December 2007 triggered a catastrophic implosion of the society, polarizing it on ethnic lines. To date, the legacy of that election is a policy paralysis: for example, the number of government ministers has been doubled with a resulting loss of policy coherence. In Zimbabwe the prospect of contested elections in 2002 and 2008 clearly failed to discipline President Mugabe into adopting good economic policies: he chose hyperinflation, using the revenues to finance patronage. The most celebrated economic reform episode in Africa is Nigeria 2003-6, when a group of technocrats led by Ngozi Nkonjo-Iweala as Minister of Finance turned the economy around. This episode was ushered in by the replacement of a military dictator, General Abacha, with an elected president, Obasanjo, suggesting that elections indeed improved government performance. However, reform only began in Obasanjo's second and final term, when he no longer faced the discipline of an election. He told Nkonjo-Iweala that the window for reform was only three years, not the full four years of his term: as he said, 'the last year will be politics'2. Indeed, that Nigeria failed to harness the first oil boom was primarily the responsibility of a democratic government, elected in 1978. That government adopted very poor economic policies, including borrowing heavily in order to finance public consumption; it was also famously corrupt. Despite its disastrous performance it was re-elected in 1983. As these examples suggest, in the conditions typical of many developing countries, elections may be two-edged swords.

The effect of elections on policy in low-income countries is of considerable importance. Since aid was first used conditionally to promote 'Structural Adjustment' in the 1980s the international community has recognized that policy improvement is fundamental to development. During the 1990s the approach to how good policies should be promoted shifted from conditionality, which was increasingly seen as both ineffective and unacceptable, to the promotion of democracy. Electorates rather than donors would coerce governments into good performance. At the core of the promotion of democracy was the promotion of elections: for example, in 2006 donors provided $\$ 500 \mathrm{~m}$ to finance elections in the Democratic Republic of the Congo. Yet the premise that elections are effective in such conditions has yet to be evaluated. At a more pragmatic level, since elections periodize political decision taking, they might also periodize policy reform: some times might be ripe for good policy. For example, it would be useful both to political leaders and to donors to know whether the year just prior to an election is indeed unsuited to policy reform as President Obasanjo evidently thought.

There is a large general literature on the relationship between democracy and economic performance but it does not provide much guidance as to these questions. The conclusion from the literature is that any such relationship is weak (Drazen, 2000; Feng, 2003; Przeworski et al., 2000). However, these studies do not focus specifically on the characteristics prevalent in developing countries many of which democratized during the 1990s. Several recent studies find that democracy has distinctive effects in the context of such characteristics. Alesina and La Ferrara (2005) and Collier (2001) focus on the consequences of ethnic diversity for growth. They find that diverse societies benefit significantly more from democracy than homogenous societies. Collier and Rohner (2008) focus on the relationship between democracy and the risk of large-scale political violence. They find that whereas in developed economies democracy increases security, below an income threshold of around $\$ 2,700$ per capita it significantly increases the risk of political violence. Finally, Collier and Hoeffler (2008) focus on the relationship between democracy and

\footnotetext{
${ }^{2}$ Personal communication to one of the authors.
} 
the economic performance of resource-rich countries. They find that whereas below a threshold of resource wealth democracy is significantly beneficial, above the threshold it significantly worsens performance. These results suggest that no simple model of how democracy affects economic policy may be globally applicable. Models designed to describe how elections affect political incentives in OECD societies may prove seriously misleading if applied to contexts such as Afghanistan and the Democratic Republic of the Congo. Our purpose in this paper is to investigate empirically the various effects of elections. As we discuss in Section 2, since there are potentially several distinct and offsetting effects, an appropriate empirical strategy needs to distinguish between them: simple composite empirical measures are likely to be misleading.

In many developing countries governments are failing to provide their citizens with the rudiments of social provision and economic opportunities now considered both normal and feasible. A reasonable inference is that in such states the ruling politicians are either ill-motivated or incompetent. We focus directly on policies rather than on economic outcomes. The typical developing country is subject to large shocks that introduce much noise into the mapping from policy choices to outcomes and we are concerned with the variables that are more directly under the control of politicians. The direct observation of policies is difficult, but in this respect the researcher is at an advantage over the electorate. We rely upon two international data sets which rate economic policies and governance, neither of which has been available to citizens of rated countries. Hence, while citizens must largely rely upon observable economic performance, we are able to observe policies directly, albeit with the limitations implied by these international rating systems. In Section 2 we discuss the theory which informs our empirical analysis. We show that while democracy may have both structural and cyclical effects on policy, a priori there are offsetting effects so that the net effect is ambiguous: the issue must therefore be resolved empirically. In Section 3 we discuss our empirical strategy: no one approach is ideal and so we test the robustness of each against the reasonable alternatives. In Section 4 we present our core results, subjecting them to a range of robustness tests in Section 5. Section 6 extends the analysis to those developing countries at the extremes of poverty and poor policies, and investigates possible interactions between elections and other political variables. Section 7 draws out the implications for policy, both in terms of international support for the process of policy reform, and for the better functioning of the new low-income democracies.

\section{A THEORETICAL OVERVIEW}

Elections can affect economic policy both through their effect on the incentives facing politicians and through selection. By making politicians accountable to citizens they increase the incentive to adopt socially beneficial economic policies. Selection is both a direct consequence of electoral choice and, more fundamentally, because if politicians are accountable the profession becomes more attractive for people who aspire to further the public good and less attractive for people who are ill-motivated (Besley, 2006). Hence, through both incentives and selection elections may enhance political motivation to adopt good policies. Further, an elected government may face lower costs of doing so. By conferring legitimacy elections might make it easier to face down vested interests that oppose reform.

However, in addition to the structural change of accountability, elections introduce friction. Elections are periodic events the timing of which may affect the incentives facing politicians. In particular, elections as events may disrupt policy. If elections affect policies both structurally and cyclically the empirical relationship between elections and policies may appear confused because of opposing effects. Elections may improve the average level of policies, yet worsen them in the short run. In this paper we try to disentangle the two effects.

\subsection{Cyclical Effects of Elections}

Elections are periodic events. One effect of an election is to create a discrete difference between the period prior to the election during which the government is in power and on which it may be judged by voters, and the period after the election when it may not be in power. This introduces an incentive for the 
government to improve its record by transferring resources from expenditures that only generate observable benefits after the election to those that generate observable benefits prior to the election. There is indeed some evidence in support of the short-term bias of democratic governments: they invest less than autocracies (Tavares and Wacziarg, 2001). Reform, by its nature, is a form of investment: short term political costs are incurred for longer term benefits. An implication is that as an election approaches the ratio of pre-election to post-election effects of policy reform falls and so the incentive to reform diminishes. Hence, the pace of reform might slow, or even become negative, as the election approaches. For example, in run-up to the Zambian election of 1991 President Kaunda increased the money supply by 400 percent, and in the run-up to the Zimbabwean election of 2008 President Mugabe confiscated foreign currency bank accounts and distributed the proceeds.

Elections are fought not just on the past record of the government but on promises: they are occasions when politicians make future policy commitments. In many developing countries the electorate lacks both the education and information properly to evaluate these commitments: the media are both highly partisan and lack the capacity for specialist analysis of economic policy, and in any case many voters are illiterate. Elections thus expose the society to the risk of political promises based on economic populism. For example, in South Africa in 2008 the electoral contest between Jacob Zuma and Thabo Mbeki for the leadership of the ruling ANC clearly pitched economic populism versus economic prudence: populism won by 9:1. A legacy of an election may therefore be a period in which policy reform is hamstrung by the need to implement some of these commitments.

Each of these short term effects of elections would give rise to a cycle, potentially in either the level of policy or the pace of reform. The shortening horizon would predict a gradual deterioration as the next election approached, while the legacy of populist commitments would predict gradual policy improvement. Empirically, there are four possibilities. Neither of the effects might be significant in which case there would be no electoral policy cycle. The shortening horizons effect might predominate, in which case the policy cycle would be a saw-tooth of post-election deterioration. The populist legacy effect might predominate, in which case the saw-tooth would have the opposite slope, with gradual post-election improvement. Finally, the potency of each effect might recede with the time to the pertinent election, forward-looking for shortening horizons, backward-looking for populist legacies. Thus, the shortening horizons effect might matter most in the period immediately prior to an election, as our examples illustrate, while the populist legacy effect might matter most in the period immediately after an election. In this case, rather than a saw-tooth, there would be a genuine cycle in which the level or pace of improvement of policy was at its peak around the mid-point between elections.

The relative importance of the two effects also determines how elections should be dated in empirical analysis. If the only significant effect is that of shortening horizons then the theory implies that the empirical measure should be forward-looking: the time to the next election. In this case, if data are organized as annual observations, an election in January has virtually no effect in the year of the election and elections in the first half of the year are better re-assigned to the previous year. Conversely, if the only significant effect is populist legacy, elections in the second half of the year are better re-assigned to the next year. Only if the two effects are similarly potent is the election best left in the year in which it occurred.

The evidence on whether political cycles are important is mixed. In developed countries, where democracies are more mature and information is good, the consensus is that there is no cycle. However, there is some evidence that cycles are significant in developing countries. To date, work has focused on budget deficits. Shi and Svensson (2006) find that political budget cycles are significantly more pronounced in developing than in developed countries. Similarly, Brender and Drazen (2005) show that in their sample of developed and developing economies political budget cycles are confined to the "new democracies". Block (2002) finds that in developing countries the fiscal deficit increases in election years and is followed by post-election retrenchments. 


\subsection{Structural effects}

Democracy is widely seen as the best system of government despite such cyclical effects. The case for democracy rests on its structural effects: increasing the accountability and legitimacy of government. The accountability effect is straightforward: faced with an election, a government may need to attract votes by adopting policies which are good for citizens, or at least good for the median voter. The legitimacy effect is not usually modelled but may also be important. It is that a government which has acquired power through winning an election has a mandate to implement its commitments and the wide recognition of this mandate reduces the ability of those opposed to these policies to block them.

Although elections hold government to account and confer legitimacy, they only do so periodically. The periodicity of elections is likely to affect the intensity of these effects as well as introducing the possibility of a cycle. A plausible hypothesis is that the greater the frequency of elections the more closely is the government held to account and the greater its legitimacy in enacting its policies. Variations in the frequency of elections thus provide an empirical measure of these structural effects.

While the 'accountability and legitimacy' model may be applicable, it is by no means inevitable. We now consider how it might be undermined, ultimately to the point at which elections have adverse structural effects on policy.

\section{Voter Ignorance}

Information about economic policy is costly and because of the free-rider problem individual voters have very little incentive to acquire it. As a result voters may not be able to monitor government performance. Besley (2006) rigorously analyzes this problem. Observable economic outcomes may be dependent upon many influences outside the control of the politician, a condition likely in the shock-prone and mediascarce conditions of many developing countries. As the ability of voters to monitor the politician deteriorates, at some point the electoral advantage from good policies becomes too small to offset the rentseeking advantages which a dishonest politician would value. Crucially, once this point is reached, rentseekers are attracted to politics, honest people are consequently discouraged, and the pool of candidates deteriorates: voters end up merely choosing among rent-seekers.

\section{Identity Voting}

Voters may hold strong ethnic allegiances which predetermine their support, making votes unresponsive to performance (Bossuroy, 2007; Fridy, 2007). This in turn weakens the incentive for governments to depart from patronage politics to provide the national public good of policy reform. For example, consider the elections of December 2007 in Kenya, which has long been regarded as one of the more successful and advanced African economies. The presidential election pitted an incumbent Kikuyu against a Luo challenger. Even among Luo voters President Kibaki had a remarkably high approval rating: those giving him a favourable rating outnumbered those disapproving by 44\%:14\% (Dercon et al., 2008). Yet $98 \%$ of Luo intended to vote for the Luo candidate. Evidently, the need to win an election provided President Kibaki little incentive to adopt policies other than those that favoured the Kikuyu. Similarly, in a remarkable field experiment in Benin in which candidates varied their electoral message randomly across localities, Wantchekon (2003) found that promises of ethnic patronage were more effective than promises of national public goods in attracting votes.

Many developing countries, especially in Africa, are highly ethnically diverse and these sub-national identities trump the relatively recent introduction of national identities (Collier, 2009). As with poor voter information, above some threshold of identity voting, the difference between good and bad policies has too little effect on voting to deter 'unprincipled' politicians from seeking office and so the pool of candidates deteriorates. 


\section{Illicit tactics}

Governments may win elections through illicit strategies such as ballot fraud, bribery and intimidation. Recent analysis of the Nigerian election by Collier and Vicente (2008) has shown that all three features were not just widespread but were used strategically. Through a randomized experiment that succeeded in reducing violence in selected locations, they are also able to show that where a party adopted the strategy of violence it was effective, reducing the turnout of those who support other parties. Similarly, in a randomized experiment in Sao Tome, Vicente (2007) was able to show that bribery was effective.

These illicit strategies may well be more than convenient supplements to the desired strategy of adopting good economic policies. If politicians are ill-motivated and wish to maintain dysfunctional policies which are personally advantageous, they may adopt the illicit strategies in order to free themselves from the need for good policies.

Whether governments are able to resort to illicit tactics depends upon dimensions of democracy other than elections. Whereas elections describe the technology by which a government acquires power, checks and balances determine how government uses power. The new democracies tend to have lop-sided democracy because elections, being discrete events, can be introduced much more readily than checks and balances, which are continuous processes. Further, the private incentive for political parties to contest elections is considerable, whereas checks and balances are public goods and so likely to be under-provided by private action. The under-provision of checks and balances is compounded because governments have an incentive not to substitute for the lack of private provision. The implication is that many of the new lowincome democracies may lack the social and constitutional pre-conditions for elections to provide an effective discipline on government performance. The most damaging scenario would be if in order to adopt the illicit strategies the government undermines the rule of law: in this case elections would induce policy deterioration. From the perspective of an ill-motivated incumbent the switch from autocracy to electoral competition may be viewed as technical regress in the retention of power. The privately optimal response may be to adopt more costly means of power retention.

Where these illicit strategies are rife an election may fail to establish the accountability of government for its performance. It may also reduce the perceived legitimacy of government. For example, once President Kibaki was perceived to have won the Kenyan election through ballot fraud, opposition to his regime was far stronger than that against the former Kenyan autocrats, Kenyatta and Moi. Combined with the undermining of checks and balances as incumbents resort to more costly strategies of power retention, elections might therefore retard reform. A recent result by Kudamatsu (2007) provides some support for this hypothesis that the consequences of elections depend upon how they are conducted. Using changes in infant mortality as a measure of the performance of African governments, he finds that only in those rare cases in which the incumbent government has lost the election does performance improve. Since the illicit tactics greatly favour incumbents, those elections in which the incumbent loses are likely to have been relatively free of such tactics.

\subsection{Implications}

The above discussion has three implications for an empirical strategy of the effect of elections on policy. First, political cycles are complicated: neither the dating of observations nor the functional form of any relationship can be determined a priori. Second, the structural effect of democracy in the conditions prevailing in many developing countries is a priori ambiguous: the triumph of accountability cannot simply be assumed. Third, if elections have both cyclical and structural effects, neither can be investigated in isolation.

As noted, in most low-income countries contested elections are recent and follow a phase of autocracy in which economic policies were highly dysfunctional. Of course, the apparent association between democracy and policy improvement may be coincidental. An alternative simple interpretation is that elites have learnt from past failure. Even if in the long run democracy leads to a better level of policy, the recent 
observed phase may be a gradual adjustment out of disequilibrium: the observable relationship may be between democracy and the rate of policy improvement towards an equilibrium level. Hence, we will investigate both the relationship in levels (and its transformation into the relationship between changes in democracy and changes in policy), and the adjustment relationship between the level of democracy and the change in policy conditional upon the attained level of policy.

\section{EMPIRICAL STRATEGY AND PRESENTATION OF THE DATA}

\subsection{Estimation Method}

The dependent variable in our analysis is economic policy and governance rather than economic performance. This has the important advantage of being under the direct control of the government, but it poses a distinct set of difficulties. Economic policies and governance are multidimensional and so must be aggregated. Some of these dimensions are not readily mapped onto a cardinal scale. Our core measure is the Country Policy and Institutional Assessment (CPIA) of the World Bank. A precise definition of the CPIA is presented in Appendix 1. It is an annual rating system for twenty different aspects of economic policy and institutions that covers around 130 countries since 1977. This has several important advantages and some severe disadvantages. It is available for a long period, 1977-2004, and is intended to be comparable across countries and, with minor qualifications, over time. It is intended to assess the overall economic efficacy of government choices regarding policies and institutions. The CPIA also has strong disadvantages. Although clear criteria are set out for the ratings, it is subjective. The ratings are given annually by economists who are staff of the World Bank specialized on the country. More senior economics staff then adjust these ratings so as to be comparable both within and across regions. A common objection to the CPIA is that it inadvertently incorporates growth outcomes: staff working on a rapidly growing economy will tend to assess policies and institutions more favourably than objectively similar policies and institutions in a slow-growing economy. A second common criticism is that the ratings reflect World Bank opinions about policy which are at times contentious. This is likely to be more serious in some contexts than others. In the range of very poor economic policies common during the 1980s in much of Africa the direction of change in World Bank ratings is likely to be fairly uncontroversial. An example is Uganda during the 1990s. There is good objective evidence of major policy improvement during this period. In the first years of the decade the Ministry of Finance lost control of the economy and inflation reached 230\%. This persuaded President Museveni to replace his economic team with a group of technocrats who had previously been critics of policy. As this group gradually gained the confidence of the president they were able to implement a widening agenda of economic policy reforms. Most notably, public spending was restrained through a 'cash budget'; the administered exchange rate was replaced first by an auction and then by an inter-bank market; the state bank was privatized; and the state monopoly on transporting coffee exports was lifted. These improvements were recognized in the international private sector: the country's rating by Institutional Investor, based on a poll of informed observers, rose from around 6/100 to over 20/100. The CPIA fully reflected these improvements, rising from a low level of 2.5 early in the decade to 4.0. The ICRG, which we will use as a robustness check, also improves from 30/100 to 60/100. All these reforms were entirely in line with standard economic analysis and so could not reasonably be seen as contentious within the profession, although they were of course contentious politically. The CPIA is likely to be more contentious within the economics profession where reforms involve a complex transition such as that which occurred in Eastern Europe. Since there were at the time open professional disputes about the pace and sequencing of reform the CPIA must be seen as merely reflecting one institutional position.

The CPIA is ordinal in nature. Each of its twenty components is rated on a scale from 1 to 6 . Because it is an average of twenty components the CPIA can take all the values within this range, as illustrated by Table 1. Our core use of this ordinal variable is to create a dummy variable which takes the value of unity in any year in which the CPIA has improved relative to the previous year. Another approach we adopt is to classify the CPIA into nine bands as shown in Table 1 and assign a ranking with which we estimate an 
ordered probit. Both of these approaches involve a loss of information. This is the price to be paid for respecting the ordinal nature of the variable: there is little sense in which an improvement from 2 to 3 is equivalent to an improvement from 3 to 4 . However, the maximum potential information is to be achieved from ignoring these concerns and treating the CPIA as though it were cardinal. We therefore also investigate these variants, both in levels and in differences. 
Table 1. Country Policy and Institutional Assessment, 1978-2004, 82 countries

\begin{tabular}{l|rr|rrr}
\hline CPIA & Ordered CPIA & \multicolumn{1}{c}{ Observations } & of which CPIA equals & Observations & Percentage \\
\hline$[1-1.5[$ & 1 & 65 & 1 & 43 & 66.2 \\
{$[1.5-2[$} & 2 & 46 & & & \\
{$[2-2.5[$} & 3 & 216 & 2 & 50 & 23.1 \\
{$[2.5-3[$} & 4 & 360 & & & \\
{$[3-3.5[$} & 5 & 589 & 3 & 157 & 26.7 \\
{$[3.5-4[$} & 6 & 313 & & & \\
{$[4-4.5[$} & 7 & 193 & 4 & 60 & 31.1 \\
{$[4.5-5[$} & 8 & 48 & & & \\
{$[5-5.5[$} & 9 & 19 & 5 & 12 & 63.2 \\
\hline & & 1849 & & 322 & \\
\hline
\end{tabular}

In our cardinal treatment of the CPIA we first estimate a model of the following form:

CPIA $_{i, t}=$ CPIA $_{i, t-1}+X_{i, t}^{\prime} \beta+$ Election $_{i, t}^{\prime} \theta+\varphi_{i}+\tau_{t}+\varepsilon_{i, t}$,

where $i(i=1 \ldots N)$ denote countries and $t(t=1 \ldots T)$ denote years. $X_{i, t}$ and Election ${ }_{i, t}$ are respectively a set of control and election variables. $\varphi_{i}$ and $\tau_{t}$ are respectively country fixed effects and years dummies.

The first way to estimate equation (1) is to use a Within estimator, which is asymptotically biased on finite $T$ (Nickell, 1981; Sevestre and Trognon, 1985). However, our sample is large (more than 1,000 observations) and the average $T$ is 23 years (the maximum being 27 years), suggesting that the bias plaguing the Within estimator is close to zero (Judson and Owen, 1999). The second way of estimating equation (1) is to transform the model in first-difference. OLS estimations of the first-difference transformation of equation (1) may still be biased because of the correlation between the lagged endogenous variable and the error term. An alternative is to use the application of the Generalized Method of Moments proposed by Arellano and Bond (1991) and to instrument $\triangle C P I A_{i, t-1}$ by its lagged values in level starting from $t-2$.

One of our ordinal strategies is to estimate an ordered probit model of the following form:

$\operatorname{CPIA}_{i, t}^{*}=\operatorname{CPIA}_{t-1}+X_{i, t}^{\prime} \beta+$ Election $_{i, t} \theta+\varphi_{i}+\tau_{t}+\varepsilon_{i, t}$,

where $\mathrm{CPIA}_{i, t}=\left\{\begin{array}{l}1 \text { if } \mu_{1}<C P I A_{i, t} \leq \mu_{2} \\ 2 \text { if } \mu_{2}<C P I A_{i, t} \leq \mu_{3} \\ \cdots \\ \mathrm{J} \text { if } \mu_{\mathrm{J}}<C P I A_{i, t} \leq \mu_{\mathrm{J}+1}\end{array}\right.$.

The other ordinal strategy is to explain positive changes in the CPIA by means of a logit model of the following form:

Change $_{i, t}=$ CPIA $_{i, t}+X_{i, t}^{\prime} \beta+$ Election $_{i, t}^{\prime} \theta+\varphi_{i}+\tau_{t}+\varepsilon_{i, t}$,

where Change $_{i, t}=\left\{\begin{array}{ll}1 & \text { if } \Delta C P I A_{i, t}>0 \\ 0 & \text { if } \Delta C P I A_{i, t} \leq 0\end{array}\right.$. 
Because equation (3) links the changes in the CPIA to level variables it may omit some important control variables. Changes in the CPIA may be more related to changes in $X_{i, t}$ than to the level of $X_{i, t}$. Equation (3) can therefore be augmented in the following way:

$$
\text { Change }_{i, t}=\text { CPIA }_{i, t}+X_{i, t}^{\prime} \beta+\Delta X_{i, t}^{\prime} \gamma+\text { Election }_{i, t} \theta+\varphi_{i}+\tau_{t}+\varepsilon_{i, t} \text {, }
$$

Of the three empirical strategies, we use the third one as our core analysis and test its robustness using the two other strategies. The choice of one strategy over the other crucially depends on how ordinal the CPIA is considered to be. The advantage of the third strategy is to respect the ordinal nature of the CPIA without making any strong econometric assumptions as to the ordinality / cardinality of the CPIA.

Finally, the choice of the CPIA as our core dependent variable is crucial to our analysis, and as noted above is not without raising substantial conceptual and econometric issues. We therefore test the robustness of our baseline model using the ICRG (International Country Risk Guide). The ICRG is a rating of countries according to their economic and political environment, which reflects the feeling of private investors. The ICRG is an alternative measure of policy and institutions which gives more weigh than the CPIA to the quality of institutions (corruption, rule of law, quality of bureaucracy, etc.). As such, it is both an interesting robustness check and a good complement to our analysis using the CPIA.

\subsection{Variables and Data}

Policy and institutions depend on a set of control variables, $X_{i, t}$, and on a set of variables relating to politics, Election ${ }_{i, t} . X_{i, t}$ include conventional development indicators: the level of income and its square, population and education. It also includes more structural characteristics such as the share of the natural resource rents in GDP, and whether the country is at war. These variables and their sources are presented in detail in Appendix 2.

Election $_{i, t}$ is a set of variables relating to the timing of elections. Data on elections are from the Database on Political Institutions (DPI) of the World Bank. To test the robustness of our results, we also use the database on elections used by Brender and Drazen (2005) and provided by Allan Drazen. Since our analysis is based on annual observations elections that occur early in the year may be more appropriately assigned to the previous year. We discuss this issue more fully in Section 4.

Knowing election years we construct four variables to precisely capture the characteristics of the electoral timing and test the cyclical and structural effects of elections raised in section 2. The first one, FREQUENCY of election, is the number of years between the current election and the previous election. We lag this variable because of its potential endogeneity with respect to the chances of reform. By lagging, we mean that if an election occurs in year $t$, FREQUENCY is equal to the number of years between election in year $t$ and the previous election. This number is reported for each year of the mandate starting in year $t^{3}$.

To construct FREQUENCY, the country obviously needs to have held at least two elections. FREQUENCY is therefore equal to 0 if the country never had an election as well as during the mandate following the first elections. To control for this characteristic of FREQUENCY, we construct two dummy variables: NEVER, which is equal to 1 for the period during which the country never had an election knowing that we have information on elections since 1975 -, and FIRST which is equal to one during the first mandate.

The fourth variable captures the political cycle. CYCLE is constructed as the number of years that separate year $t$ from the nearest election, whether this is the previous election or the next election. So if an

\footnotetext{
${ }^{3}$ We also reconstruct FREQUENCY of elections using Drazen's database. This further allows us to tackle the endogeneity issue of the timing of elections by distinguishing between predetermined and endogenous elections (see Section 5 on robustness checks).
} 
election occurs in years $t$ and $t+4$, CYCLE is equal to 0 in both years $t$ and $t+4$; it is equal to 1 in years $t+1$ and $t+3$; and it is equal to 2 in year $t+2$.

Table 2 provides some summary statistics on the dependent variables, on $X_{i, t}$ and on the various variables included in Election $_{i, t}$.

Table 2. Descriptive statistics, 1978-2004, 82 countries.

\begin{tabular}{|c|c|c|c|c|c|c|}
\hline \multicolumn{2}{|c|}{ Averages on the sample } & Obs. & Mean & St. Devia. & Minimum & Maximum \\
\hline \multirow[t]{2}{*}{ Dependent } & CPIA & 1849 & 3.13 & 0.78 & 1 & 5.5 \\
\hline & ICRG & 1273 & 60.1 & 12.5 & 13 & 83.5 \\
\hline \multirow[t]{6}{*}{ Election $_{i . t}$} & ELECTION & 1849 & 0.17 & 0.37 & 0 & 1 \\
\hline & NEVER & 1849 & 0.18 & 0.38 & 0 & 1 \\
\hline & FIRST & 1849 & 0.20 & 0.40 & 0 & 1 \\
\hline & FREQUENCY & 1849 & 3.19 & 2.99 & 0 & 19 \\
\hline & CYCLE & 1849 & 0.86 & 1.23 & 0 & 11 \\
\hline & QUALITY & 1849 & 3.31 & 3.05 & 0 & 7 \\
\hline \multirow[t]{7}{*}{$X_{i, t}$} & Ln income p.c.. lagged & 1849 & 7.98 & 0.86 & 5.14 & 9.82 \\
\hline & Income p.c. lagged & 1849 & 4059 & 3205 & 171 & 18390 \\
\hline & Secondary education. lagged & 1849 & 7.26 & 8.19 & 0.10 & 110.08 \\
\hline & Ln population. lagged & 1849 & 16.13 & 1.65 & 11.76 & 20.98 \\
\hline & Population. Lagged (in thousands) & 1849 & 49600 & 164000 & 127.8 & 1290000 \\
\hline & Natural resource rent. lagged & 1849 & 5.94 & 9.01 & 0 & 74.78 \\
\hline & Dummy AT WAR & 1849 & 0.11 & 0.32 & 0 & 1 \\
\hline \multicolumn{7}{|c|}{ Averages by countries } \\
\hline \multirow[t]{6}{*}{ Election $_{i . t}$} & Average nb of elections & 82 & 3.77 & 1.97 & 0 & 8 \\
\hline & Average nb of years before the $1^{\text {st }}$ election & 82 & 4.00 & 6.58 & 0 & 27 \\
\hline & Average nb of years of the $1^{\text {st }}$ mandate & 82 & 4.48 & 3.12 & 0 & 18 \\
\hline & Average FREQUENCY ${ }^{(1)}$ & 82 & 3.37 & 1.49 & 0 & 8 \\
\hline & Average CYCLE ${ }^{(1)}$ & 82 & 0.90 & 0.60 & 0 & 4.44 \\
\hline & Average QUALITY ${ }^{(1)}$ & 82 & 3.54 & 2.06 & 0 & 7 \\
\hline
\end{tabular}

(1): calculated on the period following the first mandate. Our sample of 1849 observations contains 82 developing countries on a period from 1978 to 2004. When we use the ICRG, this sample is reduced to 1273 observation on 70 countries on a period from 1985 to 2005.

\section{ESTIMATION OF THE BASELINE MODEL}

We now turn to our results. We investigate whether elections create pressures for better policies and governance on a sample of 82 developing countries on annual data from 1978 to 2004. A priori no single statistical approach dominates and so we present results using four different ones. Similarly, there are two distinct data sets on policy and governance, two data sets on elections, and potentially three different options for assigning elections to calendar years. Since the number of possible permutations of these options is considerable we proceed by presenting first a 'core' regression and then progressively introducing alternatives. While not all permutations are presented, all have been investigated and we note in the text those which are significantly different. Complete results are available from the authors.

In Table 3 we explore the factors that lead to a year-on-year improvement in the CPIA. We estimate Equations (3) and (4). Since the CPIA is not a cardinal variable, we analyze its change by creating a dummy variable which takes the value of unity if it has improved relative to the previous year and estimate the probability of improvement through a logit regression. Subsequently we investigate a cardinal treatment of the CPIA. 
Table 3. Logit estimations of the baseline model, 1978-2004, 82 countries.

\begin{tabular}{|c|c|c|c|c|c|c|}
\hline Dummy $=1$ if $\quad$ CPIA $>0$ & $(1)$ & $(2)$ & (3) & (4) & (5) & $(6)$ \\
\hline Dummy ELECTION (datation 1) & $\begin{array}{l}-0.102 \\
(0.68)\end{array}$ & $\begin{array}{l}-0.091 \\
(0.58)\end{array}$ & & & & \\
\hline Dummy NEVER had an election & & & $\begin{array}{l}-0.978 \\
(2.98)^{* * *}\end{array}$ & $\begin{array}{l}-0.986 \\
(2.96)^{* * *}\end{array}$ & $\begin{array}{l}-0.847 \\
(2.02)^{* *}\end{array}$ & $\begin{array}{l}-0.827 \\
(1.95)^{*}\end{array}$ \\
\hline Dummy FIRST election & & & $\begin{array}{l}-1.019 \\
(3.46)^{* * *}\end{array}$ & $\begin{array}{l}-1.026 \\
(3.47)^{* * *}\end{array}$ & $\begin{array}{l}-0.893 \\
(2.28)^{* *}\end{array}$ & $\begin{array}{l}-0.872 \\
(2.19)^{* *}\end{array}$ \\
\hline CYCLE & & & $\begin{array}{l}0.208 \\
(2.01)^{* *}\end{array}$ & $\begin{array}{l}0.204 \\
(1.92)^{*}\end{array}$ & $\begin{array}{l}0.208 \\
(2.01)^{* *}\end{array}$ & $\begin{array}{l}0.203 \\
(1.92)^{*}\end{array}$ \\
\hline CYCLE squared & & & $\begin{array}{l}-0.040 \\
(3.68)^{* * *}\end{array}$ & $\begin{array}{l}-0.041 \\
(3.65)^{* * *}\end{array}$ & $\begin{array}{l}-0.040 \\
(3.70)^{* * *}\end{array}$ & $\begin{array}{l}-0.041 \\
(3.67)^{* * *}\end{array}$ \\
\hline FREQUENCY of elections & & & $\begin{array}{l}-0.153 \\
(4.68)^{* * *}\end{array}$ & $\begin{array}{l}-0.155 \\
(4.70)^{* * *}\end{array}$ & $\begin{array}{l}-0.113 \\
(1.12)\end{array}$ & $\begin{array}{l}-0.106 \\
(1.03)\end{array}$ \\
\hline FREQUENCY squared & & & & & $\begin{array}{l}-0.003 \\
(0.44)\end{array}$ & $\begin{array}{l}-0.003 \\
(0.52)\end{array}$ \\
\hline CPIA in level, lagged & $\begin{array}{l}-1.402 \\
(8.11)^{* * *}\end{array}$ & $\begin{array}{l}-1.476 \\
(8.35)^{* * *}\end{array}$ & $\begin{array}{l}-1.466 \\
(8.55)^{* * *}\end{array}$ & $\begin{array}{l}-1.545 \\
(8.76)^{* * *}\end{array}$ & $\begin{array}{l}-1.469 \\
(8.47)^{* * *}\end{array}$ & $\begin{array}{l}-1.548 \\
(8.68)^{* * *}\end{array}$ \\
\hline Ln income p.c., lagged & $\begin{array}{l}3.760 \\
(1.63)\end{array}$ & $\begin{array}{l}4.623 \\
(1.71)^{*}\end{array}$ & $\begin{array}{l}3.275 \\
(1.43)\end{array}$ & $\begin{array}{l}4.055 \\
(1.51)\end{array}$ & $\begin{array}{l}3.282 \\
(1.44)\end{array}$ & $\begin{array}{l}4.065 \\
(1.52)\end{array}$ \\
\hline Ln income p.c. squared, lagged & $\begin{array}{l}-0.269 \\
(1.75)^{*}\end{array}$ & $\begin{array}{l}-0.328 \\
(1.83)^{*}\end{array}$ & $\begin{array}{l}-0.247 \\
(1.60)\end{array}$ & $\begin{array}{l}-0.300 \\
(1.66)^{*}\end{array}$ & $\begin{array}{l}-0.247 \\
(1.61)\end{array}$ & $\begin{array}{l}-0.300 \\
(1.67)^{*}\end{array}$ \\
\hline Secondary education, lagged & $\begin{array}{l}-0.007 \\
(0.66)\end{array}$ & $\begin{array}{l}-0.003 \\
(0.14)\end{array}$ & $\begin{array}{l}-0.000 \\
(0.01)\end{array}$ & $\begin{array}{l}0.001 \\
(0.03)\end{array}$ & $\begin{array}{l}-0.001 \\
(0.06)\end{array}$ & $\begin{array}{l}-0.000 \\
(0.01)\end{array}$ \\
\hline Ln population, lagged & $\begin{array}{l}-1.109 \\
(0.92)\end{array}$ & $\begin{array}{l}-0.962 \\
(0.83)\end{array}$ & $\begin{array}{l}-0.728 \\
(0.59)\end{array}$ & $\begin{array}{l}-0.583 \\
(0.49)\end{array}$ & $\begin{array}{l}-0.748 \\
(0.60)\end{array}$ & $\begin{array}{l}-0.605 \\
(0.50)\end{array}$ \\
\hline Resource rent, lagged & $\begin{array}{l}0.031 \\
(1.87)^{*}\end{array}$ & $\begin{array}{l}0.028 \\
(1.64)\end{array}$ & $\begin{array}{l}0.031 \\
(1.93)^{*}\end{array}$ & $\begin{array}{l}0.028 \\
(1.68)^{*}\end{array}$ & $\begin{array}{l}0.031 \\
(1.91)^{*}\end{array}$ & $\begin{array}{l}0.028 \\
(1.63)\end{array}$ \\
\hline Dummy AT WAR & $\begin{array}{l}-0.784 \\
(3.21)^{* * *}\end{array}$ & $\begin{array}{l}-0.788 \\
(3.17)^{* * *}\end{array}$ & $\begin{array}{l}-0.758 \\
(2.93)^{* * *}\end{array}$ & $\begin{array}{l}-0.761 \\
(2.89)^{* * *}\end{array}$ & $\begin{array}{l}-0.757 \\
(2.93)^{* * *}\end{array}$ & $\begin{array}{l}-0.760 \\
(2.88)^{* * *}\end{array}$ \\
\hline Ln income p.c., lagged & & $\begin{array}{l}-14.305 \\
(2.64)^{* * *}\end{array}$ & & $\begin{array}{l}-15.079 \\
(2.91)^{* * *}\end{array}$ & & $\begin{array}{l}-15.046 \\
(2.92)^{* * *}\end{array}$ \\
\hline Ln income p.c. squared, lagged & & $\begin{array}{l}1.088 \\
(2.86)^{* * *}\end{array}$ & & $\begin{array}{l}1.136 \\
(3.03)^{* * *}\end{array}$ & & $\begin{array}{l}1.134 \\
(3.05)^{* * *}\end{array}$ \\
\hline Secondary education, lagged & & $\begin{array}{l}-0.038 \\
(0.20)\end{array}$ & & $\begin{array}{l}-0.002 \\
(0.01)\end{array}$ & & $\begin{array}{l}-0.002 \\
(0.01)\end{array}$ \\
\hline Ln population, lagged & & $\begin{array}{l}6.095 \\
(0.97)\end{array}$ & & $\begin{array}{l}7.037 \\
(1.09)\end{array}$ & & $\begin{array}{l}7.111 \\
(1.10)\end{array}$ \\
\hline Resource rent, lagged & & $\begin{array}{l}0.003 \\
(0.15)\end{array}$ & & $\begin{array}{l}0.002 \\
(0.09)\end{array}$ & & $\begin{array}{l}0.003 \\
(0.11)\end{array}$ \\
\hline Constant & $\begin{array}{l}3.525 \\
(0.21)\end{array}$ & $\begin{array}{l}-1.531 \\
(0.09)\end{array}$ & $\begin{array}{l}6.505 \\
(0.37)\end{array}$ & $\begin{array}{l}-1.636 \\
(0.09)\end{array}$ & $\begin{array}{l}3.192 \\
(0.19)\end{array}$ & $\begin{array}{l}-1.782 \\
(0.10)\end{array}$ \\
\hline Observations & 1849 & 1849 & 1849 & 1849 & 1849 & 1849 \\
\hline Countries & 82 & 82 & 82 & 82 & 82 & 82 \\
\hline Turning point in CYCLE (years) & & & 2.6 & 2.5 & 2.6 & 2.5 \\
\hline Income threshold (in logarithm) & 6.99 & 7.05 & 6.63 & 6.76 & 6.64 & 6.78 \\
\hline \multicolumn{7}{|c|}{$\begin{array}{l}\text { Robust } \mathrm{z} \text { statistics in parentheses. Standard errors are adjusted for intra-country correlation. }{ }^{*} \text { significant at } 10 \% \text {; }{ }^{* *} \text { significant at } \\
5 \% ; * * * \text { significant at } 1 \% \text {. }\end{array}$} \\
\hline \multicolumn{7}{|c|}{$\begin{array}{lc}\text { DEPENDENT VARIABLE: } & \text { Dummy = } 1 \text { when CPIA is strictly positive. } \\
\text { ESTIMATION METHOD: } & \begin{array}{r}\text { Logit with country fixed effects and year dummies. } \\
\text { DATING OF ELECTIONS: }\end{array} \\
& \begin{array}{l}\text { The electoral dummy equals one in an election year and zero otherwise, no matter when during the } \\
\text { year the election occurred. NEVER, FIRST, CYCLE and FREQUENCY are constructed according to } \\
\text { this dating of elections. }\end{array}\end{array}$} \\
\hline
\end{tabular}

The first two columns provide baseline logit regressions with fixed effects and year dummies. Elections are introduced in the simplest possible form, namely a dummy variable which takes the value of unity if there is an election during the year. As with the other regressions in this table the election is assigned to the calendar year in which it occurs. The other explanatory variables are the CPIA, income and its square, secondary education, the size of the population, and the value of natural resource rents, all these variables being lagged. A dummy variable takes the value of unity if the country is at war. The regression in column (1) only the levels of these explanatory variables are included, whereas in (2) the changes in these variables are included along with their levels. 
In both regressions the dummy variable for elections is completely insignificant. Elections, the key institutional technology of democracy, appear to wash over the society without affecting economic policy. However, as we will show, this result is spurious and misleading. It may compound offsetting cyclical and structural effects, or it may reflect endogeneity. The better is the CPIA the harder it is to improve it further, the result being highly significant in both regressions. Per capita income has non-linear effects that are borderline significant: reform is most likely at around $\$ 1150$ per capita. Out of the 82 countries in our sample, only 17 have a per capita income lower than this threshold, all but Nepal in Africa. Low income thus appears to be a stimulus to change. Somewhat surprisingly, natural resource rents have positive effects that are borderline significant. This may appear to run counter to the resource curse literature. However, that literature is concerned with the long term effects and the short term effects may be benign. Unsurprisingly, civil wars have a significantly negative impact on the probability that policy and institutions will improve. Annual time dummies (not reported) suggest that policies are getting better over time. While this may reflect nothing more than grade inflation on the part of World Bank staff, it is reasonable to expect that in countries which mostly only became independent during the 1960s governments would go through a gradual learning process.

The regressions of columns 3 and 4 introduce the variables that are consistent with the discussion of theory in Section 2. Four new variables between them characterize elections. As discussed in Section 3, one is a dummy variable characterizing countries which up to the year being considered have never had an election during the period 1978-2004. A second is a dummy variable for those observations in which there has been only one prior election in the country. The third variable - CYCLE - is the time in the electoral cycle as measured by the number of years that separate the year in question from the nearest election, whether this is the previous election or the next election. Note that this conflates two potentially distinct distances: forward-looking and backward-looking. Thus, in this regression we treat the shortening horizon effect and the populist legacy effect as symmetrical. In subsequent analysis we test whether this conflation is warranted on the data. Both CYCLE and its square are included. As discussed in Section 2, the effect of the time from the nearest election is unlikely to be monotonic. While in the vicinity of the election greater distance from it might improve policy, if the nearest election is very distant then the accountability of government to the electorate may be weakened. The final new variable - FREQUENCY - captures the frequency of elections. It is measured by the length of time between the most recent previous election and the one prior to that. Hence, the higher is the value of the variable the less frequent are elections.

The control variables are the same as in the first two regressions. The regression of column (3) includes only the levels of these variables whereas that of column (4) also includes their changes. As previously, all these variables are lagged. The introduction of the new variables for elections does not significantly change the coefficients or significant levels of these control variables and so we focus on the election variables themselves.

In contrast to the naïve approach of columns (1) and (2), all the elections variables are now significant. The inclusion of the changes in the control variables in addition to their levels makes virtually no difference to either coefficients or significance levels, nearly all of which are at one percent. What do the coefficients imply?

The dummy for those countries which never held an election prior to the year under observation has a large negative coefficient. This is consistent with the hypothesis that elections introduce accountability, although the interpretation need not be causal. An alternative interpretation is that the absence of elections is a symptom of a more fundamental problem that prevents improvements in economic policy and governance rather than being its explanation. However, in addition to the control variables, recall that this regression includes fixed effects so that for all countries which did not have an election over the entire period 1978-2004 any effects of the absence of elections are subsumed in the fixed effect. Essentially, the variable NEVER is picking up the difference between periods prior to the first election and those subsequent to it: periods subsequent to elections are much more likely to have improvements in economic policy. The coefficient on observations in which the previous election was the first election is also large 
and negative, and statistically indistinguishable from that on the dummy for countries that never held elections. The most reasonable interpretation is that a single election is insufficient to change the behaviour of a government.

The remaining three variables, CYCLE, its square, and FREQUENCY, exclude the first election. We start with FREQUENCY which is the structural relationship. Recall that the variable measures the number of years between the two previous elections. Hence, an increase in the variable is a reduction in the frequency of elections. The negative coefficient therefore implies that the more frequent are elections the more likely is the CPIA to improve. This is consistent with the accountability and legitimacy theory of democracy. As with the two dummy variables for countries which have never held elections or have only held one, the frequency of elections may itself proxy some characteristics not included in our control variables, but the deep and unchanging characteristics are all subsumed by means of fixed effects.

Taken together with the negative and highly significant coefficients on the dummy variables, the negative and highly significant coefficient on FREQUENCY suggests that sustained elections really do have a structural effect on economic policy and governance, over the observed period increasing the chance of policy improvement and presumably in the long run improving the level of policy. Despite the reasons to fear that in developing countries governments might be able to win elections without regard to policy, democracy appears to work.

We now turn to CYCLE and its square. Both are significant, and whereas if the squared term is excluded CYCLE itself loses significance. CYCLE is positive and its square is negative: what does this mean? Recall that CYCLE measures the time until the nearest election, either viewed back to the previous one or forward to the next. An important issue is going to be whether this conflation of effects is warranted on the data, but for the moment we will focus on what it implies if it is warranted. The positive coefficient on CYCLE implies that the further away is an election the better are the chances of policy reform. This indicates a tension between elections as important structural instruments of democracy and as periodic events which interrupt the normal business of government. Because both effects matter, any measure which conflates them is liable to be misleading. The negative coefficient on the square of CYCLE indicates that as the distance from an election increases at some point the benefits of further distance are exhausted and go into reverse. Since FREQUENCY is included, the periodicity of elections is already controlled for. However, it implies that if the periodicity is infrequent then the mid-term is not a good time for policy reform. This becomes clearest if elections are very infrequent, such as once-a-decade. In such a case it is indeed plausible that at the mid-term the government would be less conscious of accountability to citizens.

The socially optimal periodicity of elections implied by these results depends upon the three variables in combination. This is explored further in Section 7. However, here we pose a seemingly simple question: if elections increase accountability can elections be too frequent? As the periodicity is increased there are opposing effects. The direct effect of an increased value of FREQUENCY is adverse. However, a longer periodicity also changes the average composition of the years within each period: proportionately less time is very close to an election. Up to a point, this effect is benign. Hence, for the social optimum the net effect must be calculated and this is taken up in Section 7.

The inclusion of the square of CYCLE but not the square of FREQUENCY may appear arbitrary. We first provide a degree of reassurance by adding the square of FREQUENCY in columns (5) and (6): the square is insignificant. There is indeed a good reason other than this result for the core regression to take the form of (3) and (4). Given that the structural and cyclical effects of elections are qualitatively offsetting, the minimum specification that can hope to capture optimality must include at least one squared term (or adopt some other function form which allows non-linearity). If, as appears to be the case, as periodicity is increased beyond a point the chances of reform in the mid-term period deteriorate, this can be captured better by including the square of CYCLE than the square of FREQUENCY. However, to include the square of both terms would build in redundancy. 
A fundamental aspect of the variable CYCLE is that it combines the backward and forward-looking effects of elections. In Tables 4 and 5 we investigate whether this is warranted. The conventional political economy analysis of elections is forward-looking: as the election approaches the government is less inclined to invest in policy reform because a higher proportion of the benefits will accrue after the election. If this is the only effect of elections on policy then an implication is that if analysis is based on annual observations those elections that occur in the first half of the year should be reassigned to the previous year. For example, almost all of the effects of an election held in January will be on policy decisions in the previous year. We now investigate whether such reassignment is superior to the strategy adopted in Table 3. In Table 4 we introduce dummy variables according to whether the election is in the first or second half of the year and interact them with the election variables. The key new variables are the interactions with CYCLE and its square. Evidently, since the cyclical effects are now spread over four variables instead of two, each pair with only around half as many observations, we might expect some loss of significance. However, the loss of significance is considerably more severe for the elections occurring in the first half of the year than in the second. This result suggests that the forward-looking effect of elections may be the only one of importance in which case the dating of elections should be changed accordingly. In Table 5 we therefore re-run the regressions of Table 3 but with the revised dating and compare it with Table 3. There is little to choose between the two sets of regressions. On the criterion of the $p$-values of the two cyclical variables judged on the two core regressions of columns (3) and (4) the original dating slightly outperforms: three of the four $p$-values are higher. On the criterion of the other election variables the preference for the original dating is a little stronger: in particular, the $p$-values on the two election dummy variables drop considerably with when elections in the first half of the year are reassigned to the previous year. Fortunately, the actual coefficients on the election variables are virtually unaltered. We therefore retain the calendar dating of elections, thereby implicitly giving legacy effects similar weight to anticipation effects. Quite possibly the anticipation effects are stronger than the legacy effects but not the entire story. 
Table 4. Baseline model, splitting the timing of elections, 1978-2004, 82 countries.

\begin{tabular}{|c|c|c|c|c|c|c|}
\hline Dummy $=1$ if $\quad$ CPIA $>0$ & $(1)$ & $(2)$ & $(3)$ & $(4)$ & $(5)$ & $(6)$ \\
\hline Dummy NEVER had an election & & & $\begin{array}{l}-1.159 \\
(3.44)^{* * *}\end{array}$ & $\begin{array}{l}-1.169 \\
(3.43)^{* * *}\end{array}$ & $\begin{array}{l}-0.970 \\
(2.21)^{* *}\end{array}$ & $\begin{array}{l}-0.949 \\
(2.13)^{* *}\end{array}$ \\
\hline \multicolumn{7}{|c|}{ Variables in interaction with a dummy FIRST HALF of the year } \\
\hline Dummy ELECTION & $\begin{array}{l}0.044 \\
(0.21)\end{array}$ & $\begin{array}{l}0.068 \\
(0.32)\end{array}$ & & & & \\
\hline \multicolumn{2}{|l|}{ Dummy FIRST election } & & $\begin{array}{l}-0.868 \\
(2.85)^{* * *}\end{array}$ & $\begin{array}{l}-0.871 \\
(2.87)^{* * *}\end{array}$ & $\begin{array}{l}-0.691 \\
(1.64)\end{array}$ & $\begin{array}{l}-0.665 \\
(1.56)\end{array}$ \\
\hline \multicolumn{2}{|l|}{ CYCLE } & & $\begin{array}{l}-0.008 \\
(0.03)\end{array}$ & $\begin{array}{l}-0.036 \\
(0.16)\end{array}$ & $\begin{array}{l}0.021 \\
(0.09)\end{array}$ & $\begin{array}{l}-0.008 \\
(0.03)\end{array}$ \\
\hline \multicolumn{2}{|l|}{ CYCLE squared } & & $\begin{array}{l}0.073 \\
(0.95)\end{array}$ & $\begin{array}{l}0.075 \\
(1.01)\end{array}$ & $\begin{array}{l}0.067 \\
(0.89)\end{array}$ & $\begin{array}{l}0.069 \\
(0.95)\end{array}$ \\
\hline \multicolumn{2}{|l|}{ FREQUENCY of elections } & & $\begin{array}{l}-0.149 \\
(4.16)^{* * *}\end{array}$ & $\begin{array}{l}-0.150 \\
(4.13)^{* * *}\end{array}$ & $\begin{array}{l}-0.114 \\
(1.12)\end{array}$ & $\begin{array}{l}-0.105 \\
(1.00)\end{array}$ \\
\hline \multicolumn{2}{|l|}{ FREQUENCY squared } & & & & $\begin{array}{l}-0.001 \\
(0.25)\end{array}$ & $\begin{array}{l}-0.002 \\
(0.34) \\
\end{array}$ \\
\hline \multicolumn{7}{|c|}{ Variables in interaction with a dummy SECOND HALF of the year } \\
\hline Dummy ELECTION & $\begin{array}{l}-0.250 \\
(1.09)\end{array}$ & $\begin{array}{l}-0.252 \\
(1.06)\end{array}$ & & & & \\
\hline \multicolumn{2}{|l|}{ Dummy FIRST election } & & $\begin{array}{l}-1.506 \\
(4.05)^{* * *}\end{array}$ & $\begin{array}{l}-1.522 \\
(4.03)^{* * *}\end{array}$ & $\begin{array}{l}-1.315 \\
(2.79)^{* * *}\end{array}$ & $\begin{array}{l}-1.297 \\
(2.67)^{* * *}\end{array}$ \\
\hline \multirow{2}{*}{\multicolumn{2}{|c|}{ CYCLE }} & & 0.143 & 0.154 & 0.128 & 0.139 \\
\hline & & & $(1.01)$ & $(1.06)$ & $(0.87)$ & $(0.92)$ \\
\hline \multirow{2}{*}{\multicolumn{2}{|c|}{ CYCLE squared }} & & -0.038 & -0.041 & -0.037 & -0.039 \\
\hline & & & $(2.69)^{* * *}$ & $(2.83)^{* * *}$ & $(2.52)^{* *}$ & $(2.66)^{* * *}$ \\
\hline \multirow{2}{*}{\multicolumn{2}{|c|}{ FREQUENCY of elections }} & & -0.206 & -0.211 & -0.120 & -0.113 \\
\hline & & & $(4.25)^{* * *}$ & $(4.33) * * *$ & $(0.83)$ & $(0.77)$ \\
\hline \multirow{2}{*}{\multicolumn{2}{|c|}{ FREQUENCY squared }} & & & & -0.008 & -0.009 \\
\hline & & & & & $(0.70)$ & $(0.76)$ \\
\hline \multirow[t]{2}{*}{ CPIA in level, lagged } & -1.402 & -1.477 & -1.489 & -1.564 & -1.491 & -1.566 \\
\hline & $(8.09) * * *$ & $(8.33) * * *$ & $(8.66)^{* * *}$ & $(8.88) * * *$ & $(8.63)^{* * *}$ & $(8.84)^{* * *}$ \\
\hline \multirow[t]{2}{*}{ Ln income p.c., lagged } & 3.774 & 4.650 & 3.002 & 3.862 & 2.962 & 3.800 \\
\hline & $(1.65)^{*}$ & $(1.73)^{*}$ & $(1.31)$ & $(1.44)$ & $(1.31)$ & $(1.43)$ \\
\hline \multirow[t]{2}{*}{ Ln income p.c. squared, lagged } & -0.270 & -0.331 & -0.228 & -0.287 & -0.226 & -0.284 \\
\hline & $(1.77)^{*}$ & $(1.84)^{*}$ & $(1.48)$ & $(1.58)$ & $(1.48)$ & $(1.58)$ \\
\hline \multirow[t]{2}{*}{ Secondary education, lagged } & -0.006 & -0.003 & 0.000 & 0.004 & -0.001 & 0.002 \\
\hline & $(0.63)$ & $(0.13)$ & $(0.05)$ & $(0.17)$ & $(0.06)$ & $(0.10)$ \\
\hline \multirow[t]{2}{*}{ Ln population, lagged } & -1.126 & -0.985 & -0.764 & -0.627 & -0.836 & -0.702 \\
\hline & $(0.93)$ & $(0.84)$ & $(0.61)$ & $(0.52)$ & $(0.65)$ & $(0.57)$ \\
\hline \multirow[t]{2}{*}{ Resource rent, lagged } & 0.032 & 0.028 & 0.035 & 0.032 & 0.034 & 0.032 \\
\hline & $(1.87)^{*}$ & $(1.65)^{*}$ & $(2.22)^{* *}$ & $(2.01)^{* *}$ & $(2.19)^{* *}$ & $(1.95)^{*}$ \\
\hline \multirow[t]{2}{*}{ Dummy AT WAR } & -0.792 & -0.798 & -0.772 & -0.779 & -0.775 & -0.779 \\
\hline & $(3.22)^{* * *}$ & $(3.19)^{* * *}$ & $(2.89) * * *$ & $(2.90)^{* * *}$ & $(2.90)^{* * *}$ & $(2.90)^{* * *}$ \\
\hline \multirow[t]{2}{*}{ Ln income p.c., lagged } & & -14.576 & & -14.972 & & -14.569 \\
\hline & & $(2.74)^{* * *}$ & & $(2.87)^{* * *}$ & & $(2.84)^{* * *}$ \\
\hline \multirow[t]{2}{*}{ Ln income p.c. squared, lagged } & & 1.107 & & 1.124 & & 1.100 \\
\hline & & $(2.96)^{* * *}$ & & $(2.99)^{* * *}$ & & $(2.97)^{* * *}$ \\
\hline Secondary education, lagged & & $\begin{array}{l}-0.037 \\
(0.19)\end{array}$ & & $\begin{array}{l}-0.031 \\
(0.16)\end{array}$ & & $\begin{array}{l}-0.027 \\
(0.14)\end{array}$ \\
\hline Ln population, lagged & & 6.098 & & 7.164 & & 7.453 \\
\hline Resource rent, lagged & & 0.003 & & 0.002 & & 0.003 \\
\hline & & $(0.14)$ & & $(0.07)$ & & $(0.12)$ \\
\hline Observations (countries) & $1849(82)$ & $1849(82)$ & $1849(82)$ & 1849 (82) & 1849 (82) & 1849 (82) \\
\hline $\begin{array}{l}\text { Robust z statistics in parentheses. Standard err } \\
5 \% \text {; *** significant at } 1 \% \text {. DEPENDENT VA } \\
\text { Logit with country fixed effects and year dum } \\
\text { dummy equals one in an election year and zerc } \\
\text { CYCLE and FREQUENCY are constructed ac } \\
\text { year are equal to one if the elections were held } \\
\text { duration of the mandate. }\end{array}$ & $\begin{array}{l}\text { rs are adjus } \\
\text { IABLE: Du } \\
\text { mies, consta } \\
\text { otherwise, } \\
\text { cording to t }\end{array}$ & $\begin{array}{l}\text { for intra-c } \\
\text { my }=1 \text { whe } \\
\text { included by } \\
\text { matter whe } \\
\text { dating of e }\end{array}$ & $\begin{array}{l}\text { intry correl } \\
\text { CPIA is } \\
\text { not shown. } \\
\text { during the } \\
\text { ctions. The }\end{array}$ & $\begin{array}{l}\text { ATING O } \\
\text { Ar the elect } \\
\text { ummies FI }\end{array}$ & $\begin{array}{l}\text { Int at } 10 \% \text {; } \\
\text { ESTIMATI } \\
\text { ILECTION } \\
\text { occurred. } \\
\text { T and SECC }\end{array}$ & $\begin{array}{l}\text { * significan } \\
\text { ON METHC } \\
\text { : The elect } \\
\text { EVER, FIR } \\
\text { ND half of } \\
\text { iring the wh }\end{array}$ \\
\hline
\end{tabular}


Table 5. Baseline model, alternative dating of elections, 1978-2004, 82 countries.

\begin{tabular}{|c|c|c|c|c|c|c|}
\hline Dummy $=1$ if $\quad$ CPIA $>0$ & $(1)$ & $(2)$ & (3) & (4) & (5) & (6) \\
\hline Dummy ELECTION (datation 2) & $\begin{array}{l}-0.246 \\
(1.53)\end{array}$ & $\begin{array}{l}-0.244 \\
(1.48)\end{array}$ & & & & \\
\hline Dummy NEVER had an election & & & $\begin{array}{l}-0.674 \\
(2.07)^{* *}\end{array}$ & $\begin{array}{l}-0.663 \\
(2.03)^{* *}\end{array}$ & $\begin{array}{l}-0.422 \\
(1.09)\end{array}$ & $\begin{array}{l}-0.391 \\
(1.01)\end{array}$ \\
\hline Dummy FIRST election & & & $\begin{array}{l}-0.725 \\
(2.47)^{* *}\end{array}$ & $\begin{array}{l}-0.719 \\
(2.46)^{* *}\end{array}$ & $\begin{array}{l}-0.479 \\
(1.33)\end{array}$ & $\begin{array}{l}-0.451 \\
(1.24)\end{array}$ \\
\hline CYCLE & & & $\begin{array}{l}0.217 \\
(1.98)^{* *}\end{array}$ & $\begin{array}{l}0.221 \\
(1.99)^{* *}\end{array}$ & $\begin{array}{l}0.216 \\
(1.97)^{* *}\end{array}$ & $\begin{array}{l}0.220 \\
(1.97)^{* *}\end{array}$ \\
\hline CYCLE squared & & & $\begin{array}{l}-0.039 \\
(3.12)^{* * *}\end{array}$ & $\begin{array}{l}-0.040 \\
(3.16)^{* * *}\end{array}$ & $\begin{array}{l}-0.039 \\
(3.14)^{* * *}\end{array}$ & $\begin{array}{l}-0.040 \\
(3.17)^{* * *}\end{array}$ \\
\hline FREQUENCY of elections & & & $\begin{array}{l}-0.141 \\
(4.97) * * *\end{array}$ & $\begin{array}{l}-0.142 \\
(4.95)^{* * *}\end{array}$ & $\begin{array}{l}-0.059 \\
(0.75)\end{array}$ & $\begin{array}{l}-0.053 \\
(0.64)\end{array}$ \\
\hline FREQUENCY squared & & & & & $\begin{array}{l}-0.005 \\
(1.21)\end{array}$ & $\begin{array}{l}-0.006 \\
(1.29)\end{array}$ \\
\hline CPIA, lagged & $\begin{array}{l}-1.401 \\
(8.09)^{* * *}\end{array}$ & $\begin{array}{l}-1.475 \\
(8.34)^{* * *}\end{array}$ & $\begin{array}{l}-1.444 \\
(8.68)^{* * *}\end{array}$ & $\begin{array}{l}-1.522 \\
(8.92)^{* * *}\end{array}$ & $\begin{array}{l}-1.450 \\
(8.59)^{* * *}\end{array}$ & $\begin{array}{l}-1.529 \\
(8.83)^{* * *}\end{array}$ \\
\hline Ln income p.c., lagged & $\begin{array}{l}3.728 \\
(1.63)\end{array}$ & $\begin{array}{l}4.610 \\
(1.71)^{*}\end{array}$ & $\begin{array}{l}3.434 \\
(1.51)\end{array}$ & $\begin{array}{l}4.259 \\
(1.60)\end{array}$ & $\begin{array}{l}3.493 \\
(1.56)\end{array}$ & $\begin{array}{l}4.323 \\
(1.65)^{*}\end{array}$ \\
\hline Ln income p.c. squared, lagged & $\begin{array}{l}-0.267 \\
(1.74)^{*}\end{array}$ & $\begin{array}{l}-0.328 \\
(1.83)^{*}\end{array}$ & $\begin{array}{l}-0.255 \\
(1.66)^{*}\end{array}$ & $\begin{array}{l}-0.312 \\
(1.73)^{*}\end{array}$ & $\begin{array}{l}-0.259 \\
(1.70)^{*}\end{array}$ & $\begin{array}{l}-0.315 \\
(1.78)^{*}\end{array}$ \\
\hline Secondary education, lagged & $\begin{array}{l}-0.008 \\
(0.73)\end{array}$ & $\begin{array}{l}-0.004 \\
(0.18)\end{array}$ & $\begin{array}{l}-0.002 \\
(0.24)\end{array}$ & $\begin{array}{l}-0.000 \\
(0.00)\end{array}$ & $\begin{array}{l}-0.003 \\
(0.34)\end{array}$ & $\begin{array}{l}-0.002 \\
(0.08)\end{array}$ \\
\hline Ln population, lagged & $\begin{array}{l}-1.143 \\
(0.94)\end{array}$ & $\begin{array}{l}-1.003 \\
(0.86)\end{array}$ & $\begin{array}{l}-0.913 \\
(0.76)\end{array}$ & $\begin{array}{l}-0.782 \\
(0.67)\end{array}$ & $\begin{array}{l}-0.963 \\
(0.79)\end{array}$ & $\begin{array}{l}-0.832 \\
(0.70)\end{array}$ \\
\hline Resource rent updated, lagged & $\begin{array}{l}0.032 \\
(1.89)^{*}\end{array}$ & $\begin{array}{l}0.029 \\
(1.66)^{*}\end{array}$ & $\begin{array}{l}0.033 \\
(2.07) * *\end{array}$ & $\begin{array}{l}0.030 \\
(1.83)^{*}\end{array}$ & $\begin{array}{l}0.032 \\
(2.02)^{* *}\end{array}$ & $\begin{array}{l}0.029 \\
(1.74)^{*}\end{array}$ \\
\hline Dummy AT WAR & $\begin{array}{l}-0.790 \\
(3.22)^{* * *}\end{array}$ & $\begin{array}{l}-0.795 \\
(3.19)^{* * *}\end{array}$ & $\begin{array}{l}-0.750 \\
(2.90)^{* * *}\end{array}$ & $\begin{array}{l}-0.756 \\
(2.88)^{* * *}\end{array}$ & $\begin{array}{l}-0.748 \\
(2.89)^{* * *}\end{array}$ & $\begin{array}{l}-0.752 \\
(2.86)^{* * *}\end{array}$ \\
\hline Ln income p.c., lagged & & $\begin{array}{l}-14.553 \\
(2.74)^{* * *}\end{array}$ & & $\begin{array}{l}-14.999 \\
(2.94)^{* * *}\end{array}$ & & $\begin{array}{l}-14.933 \\
(2.95)^{* * *}\end{array}$ \\
\hline Ln income p.c. squared, lagged & & $\begin{array}{l}1.103 \\
(2.95)^{* * *}\end{array}$ & & $\begin{array}{l}1.134 \\
(3.08)^{* * *}\end{array}$ & & $\begin{array}{l}1.130 \\
(3.10)^{* * *}\end{array}$ \\
\hline Secondary education, lag & & $\begin{array}{l}-0.039 \\
(0.20)\end{array}$ & & $\begin{array}{l}-0.021 \\
(0.11)\end{array}$ & & $\begin{array}{l}-0.016 \\
(0.08)\end{array}$ \\
\hline Ln population, lagged & & $\begin{array}{l}6.164 \\
(0.98)\end{array}$ & & $\begin{array}{l}6.859 \\
(1.06)\end{array}$ & & $\begin{array}{l}6.964 \\
(1.08)\end{array}$ \\
\hline Resource rent, lagged & & $\begin{array}{l}0.003 \\
(0.14)\end{array}$ & & $\begin{array}{l}0.002 \\
(0.08)\end{array}$ & & $\begin{array}{l}0.003 \\
(0.12)\end{array}$ \\
\hline Constant & $\begin{array}{l}4.023 \\
(0.24) \\
\end{array}$ & $\begin{array}{l}-0.828 \\
(0.05) \\
\end{array}$ & $\begin{array}{l}7.750 \\
(0.46) \\
\end{array}$ & $\begin{array}{l}2.201 \\
(0.12) \\
\end{array}$ & $\begin{array}{l}4.175 \\
(0.26) \\
\end{array}$ & $\begin{array}{l}-0.617 \\
(0.04) \\
\end{array}$ \\
\hline Observations & 1849 & 1849 & 1849 & 1849 & 1849 & 1849 \\
\hline $\begin{array}{l}\text { Countries } \\
\text { Turning point in CYCLE (years) }\end{array}$ & 82 & 82 & $\begin{array}{l}82 \\
2.8\end{array}$ & $\begin{array}{l}82 \\
2.8\end{array}$ & $\begin{array}{l}82 \\
2.8\end{array}$ & $\begin{array}{l}82 \\
2.8\end{array}$ \\
\hline \multicolumn{7}{|c|}{$\begin{array}{l}\text { Robust z statistics in parentheses. Standard errors are adjusted for intra-country correlation. }{ }^{*} \text { significant at } 10 \% \text {; }{ }^{* *} \text { significant at } \\
5 \% ; * * * \text { significant at } 1 \% \text {. }\end{array}$} \\
\hline \multicolumn{7}{|c|}{$\begin{array}{l}\text { DEPENDENT VARIABLE: Dummy = } 1 \text { when } \triangle \text { CPIA is strictly positive. } \\
\text { ESTIMATION METHOD: Logit with country fixed effects and year dummies. } \\
\text { SECOND DATING: } \\
\text { The electoral dummy equals one in an election year if the election occurs after June and in } \\
\text { the year before the election year it the election occurs before June. It is equal to zero } \\
\text { otherwise. NEVER, FIRST, CYCLE and FREQUENCY are constructed according to this } \\
\text { dating of elections. }\end{array}$} \\
\hline
\end{tabular}

\section{ROBUSTNESS CHECKS}

In this section, we provide a set of robustness checks of our baseline model. The CPIA has often been contested and the first robustness check is therefore to estimate the baseline model using the ICRG as an alternative measure of policy and institutions. Moreover, the chosen empirical strategy potentially loses 
information by treating the CPIA as ordinal. Our second set of robustness checks therefore explores alternative estimation methods using equations (1) and (2). A third set of robustness checks provides estimations of our baseline model using Allan Drazen's database of elections. Using this dataset also allows to explore the potential endogeneity issue of our elections variables by distinguishing between constitutionally predetermined elections and endogenous elections. Finally, our fourth set of robustness checks focuses more specifically on the CYCLE variable and proposes alternative ways of measuring political cycles.

\subsection{Estimations using the ICRG}

Our first variant on these core results is to switch from the CPIA as a measure of policy improvement to the ICRG rating. Recall that the ICRG is a commercial rating and so is subject to the discipline of the market. However, it covers fewer countries that the World Bank rating and only a period starting in $1985 .{ }^{4}$ Further, as the recent travails of the credit rating agencies indicate, the discipline of the market may in practice produce worse quality than that of an impartial public bureaucracy.

Table 6 reproduces the regressions of Table 3 with the dependent variable being a dummy which is equal to one when changes in the ICRG are positive. Among the control variables, it agrees with the World Bank data in finding that there has been an improvement in policy year-by-year that is unrelated to the other explanatory variables (the time dummies are not shown in the Table). Hence, our former result is unlikely to be fully explained by grade inflation among World Bank staff. The result is important because it severs the secular improvement in policy from the spread of democracy.

As to our election variables, it finds the same cyclical and structural effects as using the CPIA data. Although CYCLE is not individually significant its square is and so the two variables should be assessed in terms of their joint significance. The last row of Table 6 reports that CYCLE and its square are jointly significant at $5 \%$.

The ICRG gives more weight to institutions - rule of law, corruption, quality of bureaucracy, etc. - than the CPIA which is primarily focused on economic policy and structural economic reforms. A minor difference between Tables 3 and 6 is that FREQUENCY only becomes significantly negative once its square is introduced. Although the squared term is positive, within the relevant range of the data it almost never predominates. The turning point is in excess of 8 years which is found only in Liberia, Sierra Leone and Togo. The results are thus consistent with those of Table 3.

Finally, NEVER and FIRST have the same negative coefficient as in Table 3, but are less robustly significant.

\footnotetext{
${ }^{4}$ Three countries are in the ICRG database but not in the CPIA one: Barhain, Iran and Iraq. We ran the estimations with and without these countries and it did not change our results. Moreover, the ICRG is available for more recent years than the CPIA. Therefore Table 6 covers 2005, while Table 3 stopped in 2004.
} 
Table 6. Robustness checks using ICRG, 1985-2005, 70 countries.

\begin{tabular}{|c|c|c|c|c|c|c|}
\hline Dummy $=1$ if $\quad$ ICRG $>0$ & $(1)$ & $(2)$ & (3) & (4) & (5) & (6) \\
\hline Dummy ELECTION & $\begin{array}{l}0.013 \\
(0.07)\end{array}$ & $\begin{array}{l}0.009 \\
(0.05)\end{array}$ & & & & \\
\hline Dummy NEVER had an election & & & $\begin{array}{l}-0.867 \\
(1.09)\end{array}$ & $\begin{array}{l}-0.939 \\
(1.15)\end{array}$ & $\begin{array}{l}-1.905 \\
(2.00)^{* *}\end{array}$ & $\begin{array}{l}-1.905 \\
(1.93)^{*}\end{array}$ \\
\hline Dummy FIRST election & & & $\begin{array}{l}-0.331 \\
(0.63)\end{array}$ & $\begin{array}{l}-0.419 \\
(0.81)\end{array}$ & $\begin{array}{l}-1.319 \\
(1.81)^{*}\end{array}$ & $\begin{array}{l}-1.338 \\
(1.81)^{*}\end{array}$ \\
\hline CYCLE & & & $\begin{array}{l}0.083 \\
(0.68)\end{array}$ & $\begin{array}{l}0.087 \\
(0.68)\end{array}$ & $\begin{array}{l}0.074 \\
(0.61)\end{array}$ & $\begin{array}{l}0.078 \\
(0.62)\end{array}$ \\
\hline CYCLE squared & & & $\begin{array}{l}-0.029 \\
(2.04)^{* *}\end{array}$ & $\begin{array}{l}-0.026 \\
(1.82)^{*}\end{array}$ & $\begin{array}{l}-0.027 \\
(1.95)^{*}\end{array}$ & $\begin{array}{l}-0.024 \\
(1.70)^{*}\end{array}$ \\
\hline FREQUENCY of elections & & & $\begin{array}{l}-0.019 \\
(0.34)\end{array}$ & $\begin{array}{l}-0.027 \\
(0.45)\end{array}$ & $\begin{array}{l}-0.337 \\
(2.01)^{* *}\end{array}$ & $\begin{array}{l}-0.323 \\
(2.00)^{* *}\end{array}$ \\
\hline FREQUENCY squared & & & & & $\begin{array}{l}0.021 \\
(2.08)^{* *}\end{array}$ & $\begin{array}{l}0.020 \\
(2.12)^{* *}\end{array}$ \\
\hline ICRG in level, lagged & $\begin{array}{l}-0.125 \\
(6.93)^{* * *}\end{array}$ & $\begin{array}{l}-0.141 \\
(7.42)^{* * *}\end{array}$ & $\begin{array}{l}-0.130 \\
(7.32)^{* * *}\end{array}$ & $\begin{array}{l}-0.146 \\
(7.83)^{* * *}\end{array}$ & $\begin{array}{l}-0.129 \\
(7.21)^{* * *}\end{array}$ & $\begin{array}{l}-0.144 \\
(7.74)^{* * *}\end{array}$ \\
\hline Ln income p.c., lagged & $\begin{array}{l}0.951 \\
(0.21)\end{array}$ & $\begin{array}{l}0.791 \\
(0.22)\end{array}$ & $\begin{array}{l}0.471 \\
(0.11)\end{array}$ & $\begin{array}{l}0.440 \\
(0.12)\end{array}$ & $\begin{array}{l}0.733 \\
(0.17)\end{array}$ & $\begin{array}{l}0.611 \\
(0.17)\end{array}$ \\
\hline Ln income p.c. squared, lagged & $\begin{array}{l}-0.033 \\
(0.11)\end{array}$ & $\begin{array}{l}-0.028 \\
(0.12)\end{array}$ & $\begin{array}{l}0.002 \\
(0.01)\end{array}$ & $\begin{array}{l}-0.001 \\
(0.01)\end{array}$ & $\begin{array}{l}-0.016 \\
(0.06)\end{array}$ & $\begin{array}{l}-0.015 \\
(0.06)\end{array}$ \\
\hline Secondary education, lagged & $\begin{array}{l}-0.002 \\
(0.06)\end{array}$ & $\begin{array}{l}0.008 \\
(0.20)\end{array}$ & $\begin{array}{l}0.007 \\
(0.17)\end{array}$ & $\begin{array}{l}0.019 \\
(0.46)\end{array}$ & $\begin{array}{l}0.023 \\
(0.55)\end{array}$ & $\begin{array}{l}0.033 \\
(0.79)\end{array}$ \\
\hline Ln population, lagged & $\begin{array}{l}-0.165 \\
(0.10)\end{array}$ & $\begin{array}{l}-0.624 \\
(0.39)\end{array}$ & $\begin{array}{l}0.289 \\
(0.18)\end{array}$ & $\begin{array}{l}-0.093 \\
(0.06)\end{array}$ & $\begin{array}{l}0.324 \\
(0.20)\end{array}$ & $\begin{array}{l}-0.097 \\
(0.06)\end{array}$ \\
\hline Resource rent, lagged & $\begin{array}{l}0.026 \\
(0.80)\end{array}$ & $\begin{array}{l}0.025 \\
(0.86)\end{array}$ & $\begin{array}{l}0.021 \\
(0.72)\end{array}$ & $\begin{array}{l}0.020 \\
(0.75)\end{array}$ & $\begin{array}{l}0.021 \\
(0.72)\end{array}$ & $\begin{array}{l}0.020 \\
(0.76)\end{array}$ \\
\hline Dummy AT WAR & $\begin{array}{l}-1.039 \\
(2.56)^{* *}\end{array}$ & $\begin{array}{l}-0.894 \\
(1.97)^{* *}\end{array}$ & $\begin{array}{l}-1.021 \\
(2.59)^{* * *}\end{array}$ & $\begin{array}{l}-0.877 \\
(1.99)^{* *}\end{array}$ & $\begin{array}{l}-1.041 \\
(2.69)^{* * *}\end{array}$ & $\begin{array}{l}-0.895 \\
(2.06)^{* *}\end{array}$ \\
\hline . Ln income p.c., lagged & & $\begin{array}{l}10.492 \\
(1.11)\end{array}$ & & $\begin{array}{l}9.946 \\
(1.06)\end{array}$ & & $\begin{array}{l}9.708 \\
(1.01)\end{array}$ \\
\hline . Ln income p.c. squared, lagged & & $\begin{array}{l}-0.297 \\
(0.49)\end{array}$ & & $\begin{array}{l}-0.270 \\
(0.45)\end{array}$ & & $\begin{array}{l}-0.249 \\
(0.40)\end{array}$ \\
\hline . Secondary education, lagged & & $\begin{array}{l}0.128 \\
(0.47)\end{array}$ & & $\begin{array}{l}0.135 \\
(0.51)\end{array}$ & & $\begin{array}{l}0.109 \\
(0.42)\end{array}$ \\
\hline . Ln population, lagged & & $\begin{array}{l}21.013 \\
(3.00)^{* * *}\end{array}$ & & $\begin{array}{l}21.138 \\
(3.17)^{* * *}\end{array}$ & & $\begin{array}{l}20.664 \\
(3.19)^{* * *}\end{array}$ \\
\hline . Resource rent, lagged & & $\begin{array}{l}0.046 \\
(1.60)\end{array}$ & & $\begin{array}{l}0.049 \\
(1.73)^{*}\end{array}$ & & $\begin{array}{l}0.048 \\
(1.70)^{*}\end{array}$ \\
\hline Constant & $\begin{array}{l}5.244 \\
(0.26)\end{array}$ & $\begin{array}{l}12.929 \\
(0.58)\end{array}$ & $\begin{array}{l}1.733 \\
(0.09) \\
\end{array}$ & $\begin{array}{l}7.951 \\
(0.35) \\
\end{array}$ & $\begin{array}{l}1.065 \\
(0.05) \\
\end{array}$ & $\begin{array}{l}8.231 \\
(0.37) \\
\end{array}$ \\
\hline Observations & 1273 & 1273 & 1273 & 1273 & 1273 & 1273 \\
\hline Countries & 70 & 70 & 70 & 70 & 70 & 70 \\
\hline Turning point in CYCLE (years) & & & 1.4 & 1.7 & 1.4 & 1.6 \\
\hline Joint significance of CYCLE and it & -value) & & 0.019 & 0.033 & 0.025 & 0.049 \\
\hline \multicolumn{7}{|c|}{ 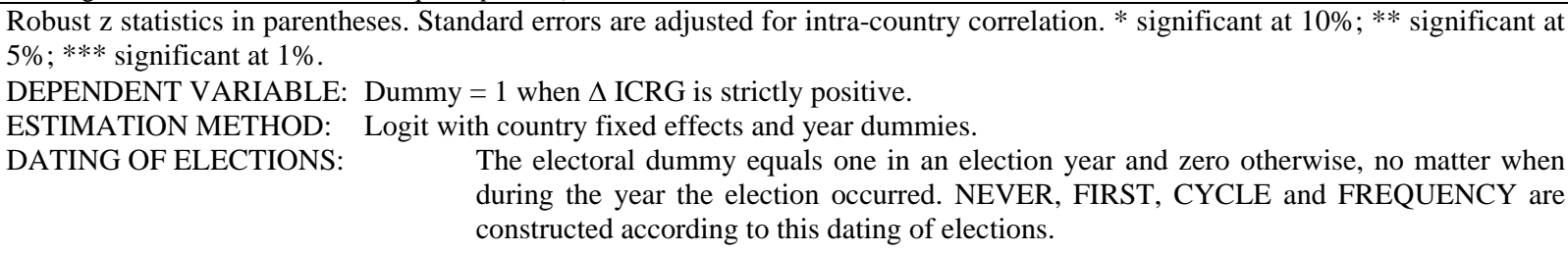 } \\
\hline
\end{tabular}

\subsection{Robustness of the estimation method: estimation of equations (1) and (2)}

We next turn to robustness checks of the estimation method. More specifically, Table 7 presents the estimations of Equation (1) - assuming continuous CPIA - using three different estimation methods: within estimator, OLS on first-difference, and Arellano and Bond (1991) GMM estimator. It also presents the estimations of Equation (2) - assuming ordered CPIA - using an ordered probit model.

These results are presented in Table 7. The most striking result is the robustness of the CYCLE effect. In Table 7, the turning point is relatively stable, between 1.7 and 2.3, and close to that of Table 3 . The coefficients on FREQUENCY, NEVER and FIRST are all always negative, as in Table 3, but they are each only significant in two of the regressions. Among the control variables, although the square of income is only significant in four of the regressions, it is always negative, as in Table 3. 
Table 7. Robustness checks of the estimation method, 1978-2004, 82 countries.

\begin{tabular}{|c|c|c|c|c|c|c|c|c|}
\hline \multirow[t]{2}{*}{ Estimation method } & \multicolumn{2}{|c|}{ WITHIN } & \multicolumn{2}{|c|}{ FIRST-DIFFERENCE } & \multicolumn{2}{|c|}{ A\&B GMM } & \multicolumn{2}{|c|}{ ORDERED PROBIT } \\
\hline & (1) & $(2)$ & (3) & (4) & (5) & (6) & (7) & $(8)$ \\
\hline Dummy NEVER had an election & $\begin{array}{l}-0.093 \\
(2.08)^{* *}\end{array}$ & $\begin{array}{l}-0.144 \\
(2.27)^{* *}\end{array}$ & $\begin{array}{l}-0.083 \\
(1.01)\end{array}$ & $\begin{array}{l}-0.095 \\
(0.74)\end{array}$ & $\begin{array}{l}-0.028 \\
(0.26)\end{array}$ & $\begin{array}{l}-0.075 \\
(0.42)\end{array}$ & $\begin{array}{l}-0.126 \\
(0.71)\end{array}$ & $\begin{array}{l}-0.331 \\
(1.38)\end{array}$ \\
\hline Dummy FIRST election & -0.075 & -0.125 & -0.080 & -0.092 & -0.031 & -0.078 & -0.080 & -0.278 \\
\hline & $(1.77)^{*}$ & $(2.09)^{* *}$ & (1.19) & $(0.78)$ & $(0.34)$ & $(0.47)$ & $(0.50)$ & $(1.29)$ \\
\hline CYCLE & $\begin{array}{l}0.027 \\
(1.97)^{*}\end{array}$ & $\begin{array}{l}0.027 \\
(1.98) *\end{array}$ & $\begin{array}{l}0.034 \\
(2.24)^{* *}\end{array}$ & $\begin{array}{l}0.034 \\
(2.24)^{* *}\end{array}$ & $\begin{array}{l}0.030 \\
(1.68)^{*}\end{array}$ & $\begin{array}{l}0.030 \\
(1.68)^{*}\end{array}$ & $\begin{array}{l}0.094 \\
(1.71)^{*}\end{array}$ & $\begin{array}{l}0.092 \\
(1.68)^{*}\end{array}$ \\
\hline CYCLE squared & $\begin{array}{l}-0.006 \\
(4.12)^{* * *}\end{array}$ & $\begin{array}{l}-0.006 \\
(4.17)^{* * *}\end{array}$ & $\begin{array}{l}-0.010 \\
(2.58)^{* *}\end{array}$ & $\begin{array}{l}-0.009 \\
(2.57)^{* *}\end{array}$ & $\begin{array}{l}-0.007 \\
(1.97)^{* *}\end{array}$ & $\begin{array}{l}-0.007 \\
(1.96)^{* *}\end{array}$ & $\begin{array}{l}-0.021 \\
(2.19)^{* *}\end{array}$ & $\begin{array}{l}-0.020 \\
(2.17)^{* *}\end{array}$ \\
\hline FREQUENCY of elections & $\begin{array}{l}-0.010 \\
(1.74)^{*}\end{array}$ & $\begin{array}{l}-0.025 \\
(1.49)\end{array}$ & $\begin{array}{l}-0.013 \\
(1.44)\end{array}$ & $\begin{array}{l}-0.017 \\
(0.54)\end{array}$ & $\begin{array}{l}-0.008 \\
(0.67)\end{array}$ & $\begin{array}{l}-0.023 \\
(0.55)\end{array}$ & $\begin{array}{l}-0.029 \\
(1.45)\end{array}$ & $\begin{array}{l}-0.091 \\
(1.66)^{*}\end{array}$ \\
\hline FREQUENCY squared & & $\begin{array}{l}0.001 \\
(0.98)\end{array}$ & & $\begin{array}{l}0.000 \\
(0.15)\end{array}$ & & $\begin{array}{l}0.001 \\
(0.42)\end{array}$ & & $\begin{array}{l}0.004 \\
(1.32)\end{array}$ \\
\hline CPIA, lagged & $\begin{array}{l}0.726 \\
(36.73)^{* * *}\end{array}$ & $\begin{array}{l}0.727 \\
(36.89)^{* * *}\end{array}$ & $\begin{array}{l}-0.049 \\
(1.71)^{*}\end{array}$ & $\begin{array}{l}-0.049 \\
(1.71)^{*}\end{array}$ & $\begin{array}{l}0.606 \\
(11.49)^{* * *}\end{array}$ & $\begin{array}{l}0.605 \\
(11.48) * * *\end{array}$ & $\begin{array}{l}2.260 \\
(19.46)^{* * *}\end{array}$ & $\begin{array}{l}2.264 \\
(19.57)^{* * *}\end{array}$ \\
\hline Ln income p.c., lagged & $\begin{array}{l}0.616 \\
(1.86)^{*}\end{array}$ & $\begin{array}{l}0.612 \\
(1.85)^{*}\end{array}$ & $\begin{array}{l}0.428 \\
(0.63)\end{array}$ & $\begin{array}{l}0.428 \\
(0.63)\end{array}$ & $\begin{array}{l}2.425 \\
(2.65)^{* * *}\end{array}$ & $\begin{array}{l}2.440 \\
(2.68)^{* * *}\end{array}$ & $\begin{array}{l}1.049 \\
(0.88)\end{array}$ & $\begin{array}{l}1.052 \\
(0.88)\end{array}$ \\
\hline Ln income p.c. squared, lagged & $\begin{array}{l}-0.048 \\
(2.08)^{* *}\end{array}$ & $\begin{array}{l}-0.048 \\
(2.07)^{* *}\end{array}$ & $\begin{array}{l}-0.020 \\
(0.42)\end{array}$ & $\begin{array}{l}-0.020 \\
(0.42)\end{array}$ & $\begin{array}{l}-0.193 \\
(3.05)^{* * *}\end{array}$ & $\begin{array}{l}-0.194 \\
(3.08)^{* * *}\end{array}$ & $\begin{array}{l}-0.091 \\
(1.12)\end{array}$ & $\begin{array}{l}-0.091 \\
(1.12)\end{array}$ \\
\hline Secondary education, lag & $\begin{array}{l}0.002 \\
(1.81)^{*}\end{array}$ & $\begin{array}{l}0.002 \\
(1.95)^{*}\end{array}$ & $\begin{array}{l}0.006 \\
(0.91)\end{array}$ & $\begin{array}{l}0.006 \\
(0.91)\end{array}$ & $\begin{array}{l}0.002 \\
(0.43)\end{array}$ & $\begin{array}{l}0.003 \\
(0.47)\end{array}$ & $\begin{array}{l}0.004 \\
(1.09)\end{array}$ & $\begin{array}{l}0.005 \\
(1.27)\end{array}$ \\
\hline Ln population, lagged & $\begin{array}{l}-0.118 \\
(0.77)\end{array}$ & $\begin{array}{l}-0.112 \\
(0.73)\end{array}$ & $\begin{array}{l}-0.470 \\
(0.76)\end{array}$ & $\begin{array}{l}-0.468 \\
(0.76)\end{array}$ & $\begin{array}{l}-0.351 \\
(0.59)\end{array}$ & $\begin{array}{l}-0.344 \\
(0.58)\end{array}$ & $\begin{array}{l}-0.763 \\
(1.60)\end{array}$ & $\begin{array}{l}-0.740 \\
(1.56)\end{array}$ \\
\hline Resource rent, lagged & $\begin{array}{l}-0.000 \\
(0.14)\end{array}$ & $\begin{array}{l}-0.000 \\
(0.13)\end{array}$ & $\begin{array}{l}0.004 \\
(1.35)\end{array}$ & $\begin{array}{l}0.004 \\
(1.34)\end{array}$ & $\begin{array}{l}0.006 \\
(1.57)\end{array}$ & $\begin{array}{l}0.006 \\
(1.57)\end{array}$ & $\begin{array}{l}-0.008 \\
(1.22)\end{array}$ & $\begin{array}{l}-0.008 \\
(1.20)\end{array}$ \\
\hline Dummy AT WAR & $\begin{array}{l}-0.119 \\
(2.94)^{* * *}\end{array}$ & $\begin{array}{l}-0.120 \\
(2.97)^{* * *}\end{array}$ & $\begin{array}{l}-0.096 \\
(1.60)\end{array}$ & $\begin{array}{l}-0.096 \\
(1.60)\end{array}$ & $\begin{array}{l}-0.052 \\
(0.73)\end{array}$ & $\begin{array}{l}-0.054 \\
(0.75)\end{array}$ & $\begin{array}{l}-0.283 \\
(1.90)^{*}\end{array}$ & $\begin{array}{l}-0.285 \\
(1.91)^{*}\end{array}$ \\
\hline Constant & $\begin{array}{l}1.205 \\
(0.45) \\
\end{array}$ & $\begin{array}{l}1.171 \\
(0.44) \\
\end{array}$ & $\begin{array}{l}0.045 \\
(3.14)^{* * *}\end{array}$ & $\begin{array}{l}0.045 \\
(3.12)^{* * *}\end{array}$ & & & & \\
\hline Observations (countries) & $1849(82)$ & $1849(82)$ & $1771(82)$ & $1771(2)$ & $1771(82)$ & $1771(82)$ & $1849(82)$ & $1849(82)$ \\
\hline $\begin{array}{l}\text { Turning point in CYCLE (years) } \\
\text { AR(1) [AR(2)] } p \text {-values } \\
\text { Hansen test } p \text {-value [nb of instruments] }\end{array}$ & 2.3 & 2.3 & 1.7 & 1.9 & $\begin{array}{l}2.1 \\
0.00[0.23] \\
1.00[97]\end{array}$ & $\begin{array}{l}2.1 \\
0.00[0.23] \\
1.00[97]\end{array}$ & 2.2 & 2.3 \\
\hline
\end{tabular}

Hansen test $p$-value [nb of instruments]

Columns (1) and (2): Within estimations of equation (1); dependent variable is continuous CPIA; estimations include year dummies.

Columns (3) and (4): Estimations in first-difference of equation (1); dependent variable is continuous CPIA; estimations include year dummies.

Columns (5) and (6): Arellano and Bond GMM estimation of equation (1) transformed in first-difference; dependent variable is continuous CPIA; estimations include year dummies; Arellano and Bond GMM estimation of equation (1) transformed in first-difference;
two-step estimator, using levels of CPIA from $t-2$ to $t-4$ as instruments for $C P I A_{i, t-1}$.

Columns (7) and (8): Estimation of ordered probit; the CPIA is ordered from 1 to 9 every 0.5 increment in the CPIA: estimations include year and country dummies.

Dating of elections: The electoral dummy equals one in an election year and zero otherwise, no matter when during the year the election occurred. NEVER, FIRST, CYCLE and FREQUENCY are constructed according to this dating of elections. 


\subsection{Predetermined versus endogenous elections}

Our third set of robustness checks of the core results is to switch from the DPI data on elections to that used by Brender and Drazen (2005) and provided by Allan Drazen on his website. The switch to Drazen's data considerably shrinks the sample (see Appendix 3), however, it has one key advantage. Drazen distinguishes between those elections which were the result of a constitutionally mandated period between elections and those which were not. The former can be regarded as predetermined events whereas the latter are potentially far more seriously contaminated by endogeneity than the lagged elections used in our core analysis. The Drazen data thus enable us to test whether our core results are likely to be spurious. We first briefly discuss the results for all elections and then distinguish between predetermined and endogenous elections focusing upon the former.

Table 8 reproduces our core regression using Drazen's database. It reproduces the significant cyclical effects but the effects of FREQUENCY are not as robust. NEVER and FIRST still have negative coefficients in all columns but are not significant.

Within the set of all elections some can be considered as predetermined and other as potentially endogenous. Columns (1) and (2) of Table 9 distinguish between the two. Predetermined elections are those which are held within the expected year of the constitutionally fixed term (Brender and Drazen, 2005). Although there is a striking difference between the results for the exogenous and potentially endogenous elections, it is not troubling for our core results. The exogenous elections have results very similar to those of our core regressions. CYCLE is significantly positive, its square is significantly negative, and FREQUENCY or its square are negative and either significant or nearly so. It is the potentially endogenous elections which fail to generate significant results. This suggests that our core results are not the spurious consequence of endogeneity.

In columns (3) and (4) of Table 9, we turn back to using the DPI database and provide an alternative test of the distinction between predetermined and potentially endogenous elections. Unfortunately, the DPI database does not provide this kind of distinction. However, we can account for the regularity of elections. Regularly held elections are more likely to be predetermined than endogenous. We therefore construct a dummy REGULAR, which is equal to one for the countries which have had the same FREQUENCY of elections during the whole period following the first mandate. We then multiply this dummy with CYCLE and FREQUENCY. The interaction terms do not alter the results for CYCLE. The number of years away from elections which maximises the chances of policy change is 2.7, close to the results of Table 3. In column (3), which replicates the form of our core regressions, the interaction terms are never significant, suggesting that the potential endogeneity of some elections is not an important issue in the regression. In column (4), where we introduce the square of FREQUENCY, its interaction with the dummy for regular elections is borderline significant and negative, suggesting that endogeneity may perhaps be weakening the adverse effects of infrequent elections 
Table 8. Robustness checks using Drazen's database, 1978-2001, 39 countries

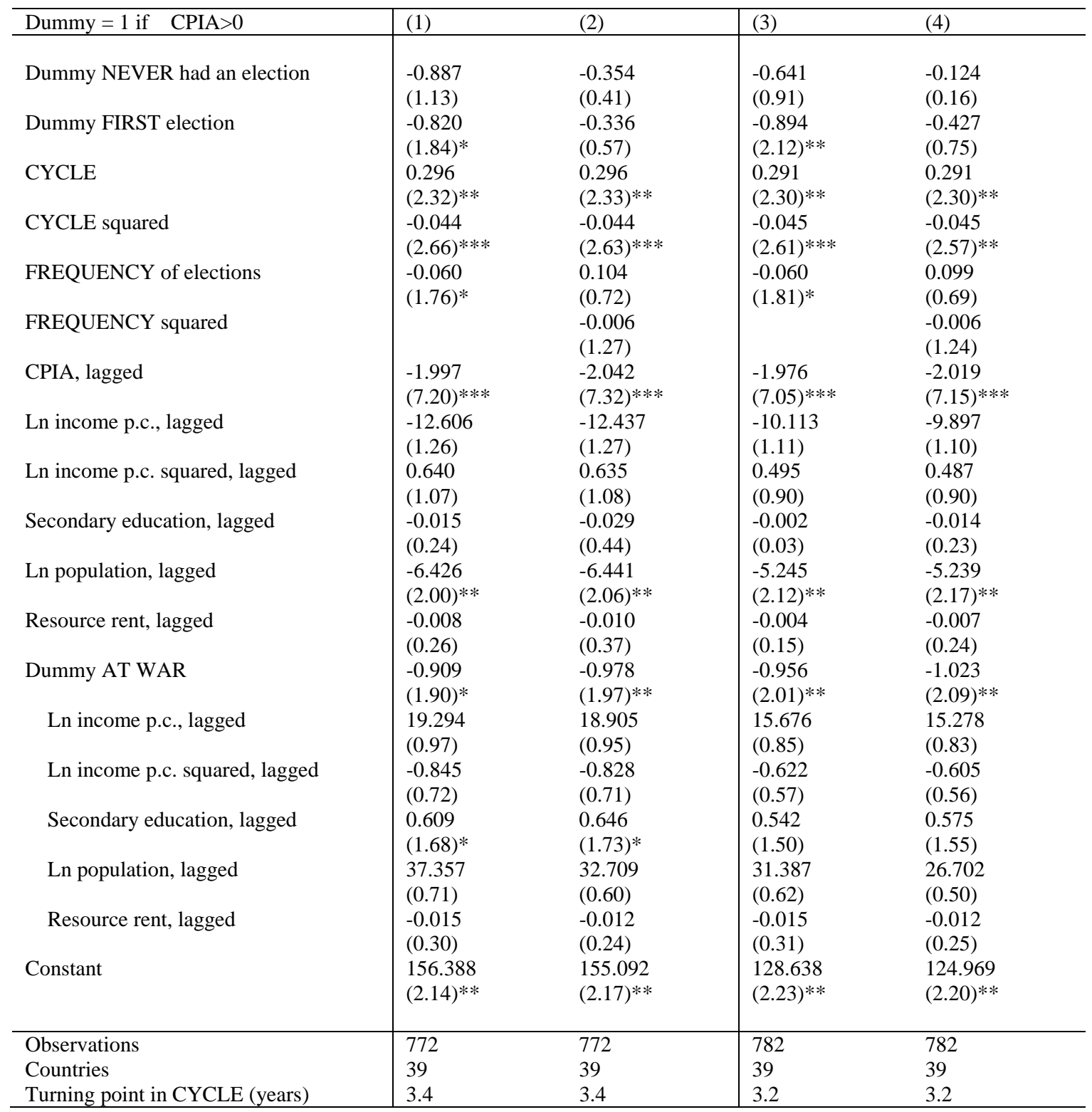

Robust $\mathrm{z}$ statistics in parentheses. Standard errors are adjusted for intra-country correlation. * significant at $10 \%$; ** significant at $5 \%$; ** significant at $1 \%$. DEPENDENT VARIABLE: Dummy $=1$ when CPIA is strictly positive. ESTIMATION METHOD: Logit with country fixed effects and year dummies. ELECTION VARIABLES: From Drazen's database. Columns (1) and (2) restrict the sample to countries included in estimations using DPI database. Columns (3) and (4) are not restricted to a sub-set of our main database which uses DPI; this leads to adding information on more years for three countries (Hungary, Romania and Poland). DATING OF ELECTIONS: The electoral dummy equals one in an election year and zero otherwise, no matter when during the year the election occurred. NEVER, FIRST, CYCLE and FREQUENCY are constructed according to this dating of elections. 
Table 9. Logit estimations of the baseline model, 1978-2001/2004, 39/82 countries.

\begin{tabular}{|c|c|c|c|c|}
\hline \multirow{2}{*}{ Dummy $=1$ if $\quad$ CPIA $>0$} & \multicolumn{2}{|c|}{ DRAZEN } & \multicolumn{2}{|c|}{ DPI } \\
\hline & $(1)$ & $(2)$ & (3) & $(4)$ \\
\hline \multirow[t]{2}{*}{ Dummy NEVER had an election } & -0.643 & 0.703 & -0.822 & -0.641 \\
\hline & $(0.74)$ & $(0.64)$ & $(2.04) * *$ & (1.37) \\
\hline \multirow[t]{2}{*}{ Dummy FIRST election } & -0.604 & 0.638 & -0.905 & -0.711 \\
\hline & $(1.36)$ & $(0.95)$ & $(2.82) * * *$ & $(1.71)^{*}$ \\
\hline Predetermined CYCLE & $\begin{array}{l}0.387 \\
(2.50)^{* *}\end{array}$ & $\begin{array}{l}0.360 \\
(2.30)^{* *}\end{array}$ & & \\
\hline \multirow[t]{2}{*}{ Predetermined CYCLE squared } & -0.057 & -0.050 & & \\
\hline & $(2.14)^{* *}$ & $(1.83)^{*}$ & & \\
\hline \multirow{2}{*}{ Predetermined FREQUENCY of elections } & -0.053 & 0.289 & & \\
\hline & $(1.52)$ & $(1.79)^{*}$ & & \\
\hline \multirow[t]{2}{*}{ Predetermined FREQUENCY squared } & & -0.012 & & \\
\hline & & $(2.26)^{* *}$ & & \\
\hline \multirow[t]{2}{*}{ Endogenous CYCLE } & 0.116 & 0.156 & & \\
\hline & $(0.45)$ & $(0.61)$ & & \\
\hline \multirow{2}{*}{ Endogenous CYCLE squared } & -0.026 & -0.031 & & \\
\hline & (1.08) & (1.25) & & \\
\hline \multirow{2}{*}{ Endogenous FREQUENCY of elections } & 0.116 & 1.132 & & \\
\hline & $(0.82)$ & $(2.15)^{* *}$ & & \\
\hline \multirow{2}{*}{ Endogenous FREQUENCY squared } & & -0.159 & & \\
\hline & & $(1.60)$ & & \\
\hline \multirow[t]{2}{*}{ CYCLE } & & & 0.235 & 0.239 \\
\hline & & & $(2.10)^{* *}$ & $(2.13)^{* *}$ \\
\hline \multirow[t]{2}{*}{ CYCLE squared } & & & -0.043 & -0.044 \\
\hline & & & $(3.79)^{* * *}$ & $(3.86)^{* * *}$ \\
\hline \multirow[t]{2}{*}{ FREQUENCY of elections } & & & -0.153 & -0.098 \\
\hline & & & $(4.63)^{* * *}$ & $(0.94)$ \\
\hline \multirow[t]{2}{*}{ FREQUENCY squared } & & & & -0.003 \\
\hline & & & & $(0.54)$ \\
\hline \multirow[t]{2}{*}{ REGULAR x CYCLE } & & & -0.183 & -0.205 \\
\hline & & & $(0.54)$ & $(0.60)$ \\
\hline \multirow[t]{2}{*}{ REGULAR x CYCLE squared } & & & 0.012 & 0.017 \\
\hline & & & $(0.22)$ & $(0.32)$ \\
\hline \multirow[t]{2}{*}{ REGULAR x FREQUENCY of elections } & & & 0.094 & 0.895 \\
\hline & & & (0.98) & $(2.16)^{* *}$ \\
\hline \multirow[t]{2}{*}{ REGULAR x FREQUENCY squared } & & & & -0.165 \\
\hline & & & & $(1.87)^{*}$ \\
\hline CPIA, lagged & -2.028 & -2.089 & -1.554 & -1.563 \\
\hline & $(7.15)^{* * *}$ & $(7.07)^{* * *}$ & $(8.55)^{* * *}$ & $(8.46)^{* * *}$ \\
\hline Ln income p.c., lagged & -11.989 & -15.557 & 4.097 & 4.066 \\
\hline & $(1.20)$ & $(1.50)$ & $(1.41)$ & $(1.42)$ \\
\hline Ln income p.c. squared, lagged & 0.603 & 0.815 & -0.305 & -0.300 \\
\hline & $(1.01)$ & $(1.32)$ & $(1.56)$ & $(1.55)$ \\
\hline Secondary education, lagged & -0.002 & -0.024 & 0.001 & 0.000 \\
\hline & $(0.02)$ & $(0.37)$ & $(0.04)$ & $(0.01)$ \\
\hline Ln population, lagged & -6.326 & -6.528 & -0.662 & -0.636 \\
\hline & $(1.95)^{*}$ & $(2.04)^{* *}$ & $(0.55)$ & $(0.52)$ \\
\hline Resource rent, lagged & -0.002 & -0.007 & 0.028 & 0.027 \\
\hline & $(0.06)$ & $(0.26)$ & $(1.68)^{*}$ & $(1.57)$ \\
\hline Dummy AT WAR & -0.973 & -1.001 & -0.767 & -0.772 \\
\hline & $(2.02)^{* *}$ & $(2.02)^{* *}$ & $(2.89) * * *$ & $(2.90) * * *$ \\
\hline
\end{tabular}


Table 9. Continued.

\begin{tabular}{l|ll|ll}
\hline$\Delta$ Ln income p.c., lagged & 19.824 & 21.027 & -15.053 & -14.739 \\
& $(1.01)$ & $(1.09)$ & $(2.90)^{* * *}$ & $(2.83)^{* * *}$ \\
& -0.880 & -0.958 & 1.136 & 1.114 \\
$(2.97)^{* * *}$ \\
L Ln income p.c. squared, lagged & $(0.75)$ & $(0.84)$ & $(3.03)^{* * *}$ & -0.009 \\
& 0.614 & 0.606 & -0.009 & $(0.05)$ \\
$\Delta$ Secondary education, lagged & $(1.70) *$ & $(1.70)^{*}$ & $(0.05)$ & 7.048 \\
& 38.473 & 39.895 & 7.115 & $(1.10)$ \\
$\Delta$ Ln population, lagged & $(0.74)$ & $(0.74)$ & $(1.12)$ & 0.002 \\
& -0.017 & -0.017 & 0.001 & $(0.10)$ \\
Resource rent, lagged & $(0.34)$ & $(0.34)$ & $(0.05)$ & -1.350 \\
& 152.100 & 174.355 & -0.858 & $(0.07)$ \\
Constant & $(2.06)^{* *}$ & $(2.26) * *$ & $(0.05)$ & $1849(82)$ \\
\hline
\end{tabular}

\subsection{Alternative measures of CYCLE}

Finally our last set of robustness checks focuses on CYCLE. In the way we construct CYCLE, we implicitly assume some symmetry between the backward and forward-looking effects of elections discussed in Section 2. CYCLE is a mix of two variables: the time since the last election and the time to the next election. In the first column of Table 10 we reproduce the estimation of our baseline model. In columns (2) and (3), while retaining the composite CYCLE variable and its square, we add one of the two components, namely the number of years since the last election and its square. By introducing one of the two, we allow for some asymmetry in the treatment of these two components of CYCLE. If the two components had very different effects we would expect this to be revealed by significant coefficients on the added variable, positive or negative according to which component was key. In fact, adding these two variables does not alter the CYCLE result, nor the optimal year for policy change (around 2.8 years), and the added variables are insignificant.

Finally, in column (4), we disaggregate CYCLE into four dummy variables. The first one is equal to one in the year following and in the year preceding an election. The second dummy is equal to one in the second years following and preceding an election. Because the average FREQUENCY of elections in our sample is lower than 4 years, we create four dummies of this kind. However, adding more of them does not alter the results of column (4). The coefficients of these four variables gradually increase up to the third dummy and start decreasing for the fourth one. Consistently with our previous results, three years away from elections seems to be the best timing for policy improvement. However, this set of dummies is not significant. Only the third one is close to significance with a $p$-value of 0.11 . 
Table 10. Robustness to alternative measures of CYCLE, 1978-2004, 82 countries.

\begin{tabular}{|c|c|c|c|c|}
\hline Dummy $=1$ if $\quad$ CPIA $>0$ & $(1)$ & $(2)$ & $(3)$ & $(4)$ \\
\hline Dummy NEVER had an election & $\begin{array}{l}-0.986 \\
(2.96)^{* * *}\end{array}$ & $\begin{array}{l}-0.991 \\
(2.96)^{* * *}\end{array}$ & $\begin{array}{l}-0.988 \\
(2.94)^{* * *}\end{array}$ & $\begin{array}{l}-0.960 \\
(2.83) * * *\end{array}$ \\
\hline Dummy FIRST election & $\begin{array}{l}-1.026 \\
(3.47)^{* * *}\end{array}$ & $\begin{array}{l}-1.038 \\
(3.46)^{* * *}\end{array}$ & $\begin{array}{l}-1.035 \\
(3.42)^{* * *}\end{array}$ & $\begin{array}{l}-0.982 \\
(3.30)^{* * *}\end{array}$ \\
\hline FREQUENCY of elections & $\begin{array}{l}-0.155 \\
(4.70)^{* * *}\end{array}$ & $\begin{array}{l}-0.156 \\
(4.67)^{* * *}\end{array}$ & $\begin{array}{l}-0.157 \\
(4.67)^{* * *}\end{array}$ & $\begin{array}{l}-0.155 \\
(4.55)^{* * *}\end{array}$ \\
\hline CYCLE & $\begin{array}{l}0.204 \\
(1.92)^{*}\end{array}$ & $\begin{array}{l}0.243 \\
(2.14)^{* *}\end{array}$ & $\begin{array}{l}0.231 \\
(1.84)^{*}\end{array}$ & \\
\hline CYCLE squared & $\begin{array}{l}-0.041 \\
(3.65)^{* * *}\end{array}$ & $\begin{array}{l}-0.043 \\
(3.75)^{* * *}\end{array}$ & $\begin{array}{l}-0.042 \\
(3.64)^{* * *}\end{array}$ & \\
\hline Number of years since last election & & $\begin{array}{l}-0.029 \\
(0.71)\end{array}$ & $\begin{array}{l}-0.016 \\
(0.18)\end{array}$ & \\
\hline Number of years since last election, squared & & & $\begin{array}{l}-0.001 \\
(0.25)\end{array}$ & \\
\hline One year away from past and next election & & & & $\begin{array}{l}0.193 \\
(1.02)\end{array}$ \\
\hline Two years away from past and next election & & & & $\begin{array}{l}0.252 \\
(1.36)\end{array}$ \\
\hline Three years away from past and next election & & & $(p$-value $=0.114)$ & $\begin{array}{l}0.607 \\
(1.58)\end{array}$ \\
\hline Four years away from past and next election & & & & $\begin{array}{l}0.295 \\
(0.84)\end{array}$ \\
\hline CPIA, lagged & $\begin{array}{l}-1.545 \\
(8.76)^{* * *}\end{array}$ & $\begin{array}{l}-1.540 \\
(8.76)^{* * *}\end{array}$ & $\begin{array}{l}-1.540 \\
(8.75)^{* * *}\end{array}$ & $\begin{array}{l}-1.525 \\
(8.87)^{* * *}\end{array}$ \\
\hline Ln income p.c., lagged & $\begin{array}{l}4.055 \\
(1.51)\end{array}$ & $\begin{array}{l}3.624 \\
(1.22)\end{array}$ & $\begin{array}{l}3.527 \\
(1.19)\end{array}$ & $\begin{array}{l}4.324 \\
(1.68)^{*}\end{array}$ \\
\hline Ln income p.c. squared, lagged & $\begin{array}{l}-0.300 \\
(1.66)^{*}\end{array}$ & $\begin{array}{l}-0.274 \\
(1.40)\end{array}$ & $\begin{array}{l}-0.269 \\
(1.38)\end{array}$ & $\begin{array}{l}-0.316 \\
(1.80)^{*}\end{array}$ \\
\hline Secondary education, lagged & $\begin{array}{l}0.001 \\
(0.03)\end{array}$ & $\begin{array}{l}0.000 \\
(0.02)\end{array}$ & $\begin{array}{l}0.001 \\
(0.03)\end{array}$ & $\begin{array}{l}0.001 \\
(0.03)\end{array}$ \\
\hline Ln population, lagged & $\begin{array}{l}-0.583 \\
(0.49)\end{array}$ & $\begin{array}{l}-0.532 \\
(0.45)\end{array}$ & $\begin{array}{l}-0.506 \\
(0.42)\end{array}$ & $\begin{array}{l}-0.712 \\
(0.61)\end{array}$ \\
\hline Resource rent, lagged & $\begin{array}{l}0.028 \\
(1.68)^{*}\end{array}$ & $\begin{array}{l}0.028 \\
(1.62)\end{array}$ & $\begin{array}{l}0.028 \\
(1.61)\end{array}$ & $\begin{array}{l}0.029 \\
(1.78)^{*}\end{array}$ \\
\hline Dummy AT WAR & $\begin{array}{l}-0.761 \\
(2.89)^{* * *}\end{array}$ & $\begin{array}{l}-0.749 \\
(2.88)^{* * *}\end{array}$ & $\begin{array}{l}-0.746 \\
(2.84)^{* * *}\end{array}$ & $\begin{array}{l}-0.784 \\
(3.02)^{* * *}\end{array}$ \\
\hline Ln income p.c., lagged & $\begin{array}{l}-15.079 \\
(2.91)^{* * *}\end{array}$ & $\begin{array}{l}-15.086 \\
(2.87)^{* * *}\end{array}$ & $\begin{array}{l}-14.982 \\
(2.80)^{* * *}\end{array}$ & $\begin{array}{l}-13.550 \\
(2.61)^{* * *}\end{array}$ \\
\hline Ln income p.c. squared, lagged & $\begin{array}{l}1.136 \\
(3.03)^{* * *}\end{array}$ & $\begin{array}{l}1.137 \\
(3.00)^{* * *}\end{array}$ & $\begin{array}{l}1.131 \\
(2.94)^{* * *}\end{array}$ & $\begin{array}{l}1.036 \\
(2.76)^{* * *}\end{array}$ \\
\hline Secondary education, lagged & $\begin{array}{l}-0.002 \\
(0.01)\end{array}$ & $\begin{array}{l}-0.001 \\
(0.00)\end{array}$ & $\begin{array}{l}-0.002 \\
(0.01)\end{array}$ & $\begin{array}{l}-0.010 \\
(0.05)\end{array}$ \\
\hline Ln population, lagged & $\begin{array}{l}7.037 \\
(1.09)\end{array}$ & $\begin{array}{l}6.759 \\
(1.05)\end{array}$ & $\begin{array}{l}6.739 \\
(1.05)\end{array}$ & $\begin{array}{l}6.236 \\
(0.98)\end{array}$ \\
\hline Resource rent, lagged & $\begin{array}{l}0.002 \\
(0.09)\end{array}$ & $\begin{array}{l}0.002 \\
(0.10)\end{array}$ & $\begin{array}{l}0.002 \\
(0.09)\end{array}$ & $\begin{array}{l}0.002 \\
(0.07)\end{array}$ \\
\hline Constant & $\begin{array}{l}-1.636 \\
(0.09)\end{array}$ & $\begin{array}{l}-0.396 \\
(0.02)\end{array}$ & $\begin{array}{l}2.274 \\
(0.12)\end{array}$ & $\begin{array}{l}-1.346 \\
(0.08)\end{array}$ \\
\hline Observations & 1849 & 1849 & 1849 & 1849 \\
\hline Countries & 82 & 82 & 82 & 82 \\
\hline Turning point in CYCLE (years) & 2.5 & 2.8 & 2.8 & \\
\hline
\end{tabular}




\section{EXTENSIONS}

We now extend the analysis to investigate whether there are significant differences in our results according to the characteristics of countries.

Doubts over the efficacy of elections in developing countries are particularly centred on the scope for subverting them. Incumbents can resort to several illicit means of retaining power. Our results so far have suggested that accountability works: by requiring governments to attract votes, elections induce them to adopt improved economic policies and governance. Potentially, if governments can retain power by other means they need not adjust policies to those wanted by the electorate but not by politicians themselves. We first investigate whether there is any quantitative evidence that the conduct of elections indeed affects economic policy. For this we rely upon an ordinal indicator of the quality of elections (see Appendix 2 for a precise definition). As might be expected, this indicator is itself of doubtful value. In particular, it does not use the assessment of external monitors who now often rate elections according to whether they are 'free and fair'. However, it does assess them by the objective indicator of the proportion of seats won by the opposition. Unfortunately, while this is an indicator of whether the election was conducted in a manner than enabled the opposition to gain seats, it is also one that is evidently endogenous to government performance. Other things equal, an opposition will be more likely to win seats if the government has adopted, or looks likely to adopt, very poor economic policies. Hence, the quality indicator will be high not only in situations in which the electorate can indeed discipline the government by voting, but in situations in which the government has particularly failed to deliver what voters want. While we would expect the former effect to produce a positive link between the measured quality of elections and the chance of good policy, the latter effect is liable to produce the opposite association due to reverse causality. This provides an important caveat: our measure, QUALITY, is likely to be biased against clear results.

Table 11 presents the results. We introduce QUALITY both directly and interacted with the structural political variable FREQUENCY across all seven of our approaches. The direct effect of QUALITY is significant in two of these regressions when using the ICRG as dependent variable, in both being positive. The more important issue is whether, controlling for this direct effect, QUALITY affects the structural efficacy of elections. In three of the seven regressions the interaction is significant, and in a fourth it is close to being so, in all four cases being negative. Further, in all four the coefficient on FREQUENCY now changes sign and becomes positive, sometimes significantly so. Yet more striking, in two of the remaining three regressions where the interaction is not significant, its addition destroys the significantly negative direct effect of FREQUENCY, this being the channel that captures the structural accountability effect of elections. Only in the regression of column (1) in which the dependent variable is the direction of change in the CPIA does it survive, but this is contradicted by the ordered probit results for the CPIA in column (7), which arguably captures more information from the CPIA data, where the coefficient switches to being positive. 
Table 11. Quality of elections, 1978-2004 on 82 countries for CPIA, 1985-2005 on 70 countries for ICRG.

\begin{tabular}{|c|c|c|c|c|c|c|c|}
\hline \multirow[t]{2}{*}{$\begin{array}{l}\text { Dependent variable } \\
\text { Estimation method }\end{array}$} & \multicolumn{2}{|c|}{$\begin{array}{cc}\text { Dummy }=1 \text { when } & >0 \\
\text { LOGIT }+ \text { FE }\end{array}$} & \multicolumn{2}{|c|}{$\begin{array}{l}\text { Continuous } \\
\text { WITHIN }\end{array}$} & \multicolumn{2}{|c|}{$\begin{array}{c}\text { Continuous } \\
\text { FIRST-DIFFERENCE }\end{array}$} & \multirow{2}{*}{$\begin{array}{l}\text { Ordered CPIA (0-9) } \\
\text { ORDERED PROBIT } \\
\text { CPIA } \\
\text { (7) }\end{array}$} \\
\hline & $\begin{array}{l}\text { CPIA } \\
\text { (1) }\end{array}$ & $\begin{array}{l}\text { ICRG } \\
\text { (2) }\end{array}$ & $\begin{array}{l}\text { CPIA } \\
\text { (3) }\end{array}$ & $\begin{array}{l}\text { ICRG } \\
\text { (4) }\end{array}$ & $\begin{array}{l}\text { CPIA } \\
\text { (5) }\end{array}$ & $\begin{array}{l}\text { ICRG } \\
(6)\end{array}$ & \\
\hline Dummy NEVER had an election & -0.766 & -0.179 & -0.002 & 0.301 & -0.093 & -0.027 & 0.432 \\
\hline & $(1.26)$ & $(0.16)$ & $(0.02)$ & $(0.30)$ & $(0.85)$ & $(0.02)$ & $(1.40)$ \\
\hline Dummy FIRST election & -0.738 & 0.298 & 0.027 & 0.209 & -0.090 & -0.118 & 0.534 \\
\hline & $(1.20)$ & $(0.29)$ & $(0.30)$ & $(0.22)$ & $(0.84)$ & $(0.10)$ & $(1.70)^{*}$ \\
\hline CYCLE & 0.218 & 0.062 & 0.029 & -0.068 & 0.034 & 0.104 & 0.102 \\
\hline & $(2.02)^{* *}$ & $(0.49)$ & $(2.11)^{* *}$ & $(0.47)$ & $(2.18)^{* *}$ & $(0.77)$ & $(1.86)^{*}$ \\
\hline CYCLE squared & $\begin{array}{l}-0.042 \\
(3.70) * * *\end{array}$ & $\begin{array}{l}-0.024 \\
(168) *\end{array}$ & $\begin{array}{l}-0.006 \\
(4.22)^{* * *}\end{array}$ & -0.028 & -0.009 & -0.054 & -0.022 \\
\hline FREQUENCY of elections & -0.177 & 0.181 & -0.001 & 0.330 & -0.014 & 0.240 & $\begin{array}{l}(2.04)^{2 *} \\
0.041\end{array}$ \\
\hline & $(2.12)^{* *}$ & $(1.34)$ & $(0.09)$ & $(2.44)^{* *}$ & $(0.70)$ & (1.43) & $(0.95)$ \\
\hline QUALITY of elections (1-7) & 0.055 & 0.159 & 0.022 & 0.310 & -0.002 & 0.266 & 0.131 \\
\hline FREQUENCY x QUALITY & $\begin{array}{l}0.007 \\
(0.37)\end{array}$ & $\begin{array}{l}-0.045 \\
(1.81)^{*}\end{array}$ & $\begin{array}{l}-0.002 \\
(0.69)\end{array}$ & $\begin{array}{l}-0.090 \\
(3.03)^{* * *}\end{array}$ & $\begin{array}{l}0.000 \\
(0.08)\end{array}$ & $\begin{array}{l}-0.077 \\
(2.47)^{* *}\end{array}$ & $\begin{array}{l}-0.015 \\
(1.58)(p \text {-value }=0.113)\end{array}$ \\
\hline Dependent variable in level, lagged & -1.569 & $\begin{array}{l}-0.146 \\
\end{array}$ & 0.725 & 0.799 & $\begin{array}{l}-0.049 \\
-0.049\end{array}$ & 0.152 & 2.258 \\
\hline 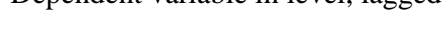 & $(8.51)^{* * *}$ & $(7.76)^{* * *}$ & $(35.94) * * *$ & $(38.46)^{* * *}$ & $(1.70)^{*}$ & $(4.97)^{* * *}$ & $(19.43) * * *$ \\
\hline Ln income p.c., lagged & 3.925 & 0.438 & 0.604 & 1.750 & 0.428 & 20.359 & 1.059 \\
\hline & $(1.45)$ & $(0.12)$ & $(1.79)^{*}$ & $(0.35)$ & $(0.63)$ & (1.58) & $(0.85)$ \\
\hline Ln income p.c. squared, lagged & -0.295 & 0.001 & -0.047 & -0.171 & -0.020 & -1.042 & -0.092 \\
\hline & $(1.63)$ & $(0.00)$ & $(2.04)^{* *}$ & $(0.51)$ & $(0.42)$ & $(1.22)$ & (1.09) \\
\hline Secondary education, lagged & 0.001 & 0.025 & 0.002 & 0.039 & 0.006 & 0.099 & 0.006 \\
\hline & $(0.04)$ & $(0.60)$ & $(1.92)^{*}$ & $(0.70)$ & $(0.90)$ & $(0.55)$ & (1.38) \\
\hline Ln population, lagged & -0.393 & -0.075 & -0.076 & 1.610 & -0.473 & 13.216 & -0.549 \\
\hline & $(0.32)$ & $(0.05)$ & $(0.49)$ & $(0.87)$ & $(0.77)$ & $(1.42)$ & (1.13) \\
\hline Resource rent, lagged & 0.028 & 0.019 & -0.000 & 0.051 & 0.004 & 0.169 & -0.008 \\
\hline Dummy AT WAR & $\begin{array}{l}(1.72)^{*} \\
-0.749\end{array}$ & $\begin{array}{l}(0.71) \\
-0.894\end{array}$ & $\begin{array}{l}(0.18) \\
-0.117\end{array}$ & $\begin{array}{l}(1.26) \\
-1.216\end{array}$ & $\begin{array}{l}(1.35) \\
-0.096\end{array}$ & $\begin{array}{l}(3.92)^{* * *} \\
-1.635\end{array}$ & $\begin{array}{l}(1.34) \\
-0.269\end{array}$ \\
\hline & $(2.82)^{* * *}$ & $(2.03)^{* *}$ & $(2.90)^{* * *}$ & $(1.79)^{*}$ & $(1.60)$ & $(2.59)^{* *}$ & $(1.81)^{*}$ \\
\hline . Ln income p.c., lagged & -14.794 & 9.177 & & & & & \\
\hline . Ln income p.c. squared, lagged & $\begin{array}{l}1.123 \\
(3.05)^{* * *}\end{array}$ & $\begin{array}{l}-0.223 \\
(0.36)\end{array}$ & & & & & \\
\hline$\Delta$. Secondary education, lagged & $\begin{array}{l}-0.003 \\
(0.02)\end{array}$ & $\begin{array}{l}0.129 \\
(0.49)\end{array}$ & & & & & \\
\hline$\Delta$. Ln population, lagged & 7.408 & 20.044 & & & & & \\
\hline$\Delta$. Resource rent updated, lagged & $\begin{array}{l}(1.13) \\
0.003\end{array}$ & $\begin{array}{l}(3.17)^{* * *} \\
0.049\end{array}$ & & & & & \\
\hline & $(0.15)$ & $(1.72)^{*}$ & & & & & \\
\hline Constant & $\begin{array}{l}-0.037 \\
(0.00)\end{array}$ & $\begin{array}{l}6.848 \\
(0.31)\end{array}$ & $\begin{array}{l}0.472 \\
(0.17)\end{array}$ & $\begin{array}{l}-20.575 \\
(0.78)\end{array}$ & $\begin{array}{l}0.045 \\
(3.12)^{* * *}\end{array}$ & $\begin{array}{l}0.515 \\
(2.58)^{* *}\end{array}$ & \\
\hline Observations (countries) & $1849(82)$ & $1273(70)$ & $1849(82)$ & $1273(70)$ & $1771(82)$ & $1206(70)$ & $1849(82)$ \\
\hline
\end{tabular}

All regressions include year dummies. Robust z statistics in parentheses. Standard errors are adjusted for intra-country correlation * significant at $10 \% \cdot * *$ significant at $5 \% ; * * *$ significant at $1 \%$. The electoral dummy equals one in an election year and zero otherwise, no matter when during the year the election occurred. NEVER, FIRST, CYCLE and FREQUENCY are constructed according to this dating of elections. (1): p-value. 
Taking these results as reliable for the moment, the meaning of this conjunction of coefficients is that frequent elections that are not of reasonable quality do not induce good economic policies and governance. On the contrary, they are more likely to lead to deterioration. It is only well-conducted elections that have the favourable structural effects on policy and governance. With the favourable structural effect lost, the only remaining effect of elections is cyclical: the further away is the society from an election the more likely is the government to improve policy and governance. However, this conclusion comes with a double caveat. The effect of QUALITY is notably less robust than our core results, and the variable, by its definition, is problematic.

Finally, we investigate whether our results hold for the particular circumstances of low-income countries and most especially, for those among them which have had a phase of very poor policies and governance. In Table 12, columns (1) to (4) the sample is restricted to low-income countries. We might expect that with the reduction in sample size there would be some loss of significance and this is indeed the case. However, in the core regession of column (1) the three key election variables all remain significant and their coefficients are virtually identical to the results from the full sample of developing countries. Hence, there appears to be no important distinctive effect of low income.

In regressions (5) to (8) we further restrict the sample to 'failing states', these being countries which at some time during the observed period had very poor policies, defined as a CPIA score below 2.5. This level is commonly recognized by World Bank staff as being a threshold below which policies and governance are seen as overall highly problematic. Column (5) reruns our core regression. All five election variables remain significant. This is an important result in that it suggests that our analysis is applicable in these contexts in which the improvement of economic policies and governance is most needed. The coefficient on FREQUENCY, which we have suggested captures the structural effect of accountability to the electorate, is virtually identical to that for the entire sample: elections appear to produce accountability over a wide range of economic development. The coefficients on CYCLE and its square are both somewhat larger than those for the full sample. Since the full sample of course contains this sub-sample is suggests that the cyclical effects may be more pronounced in failing states than in other developing countries.

The final results concern the effects of adding QUALITY interacted with FREQUENCY to the regressions, both for low-income countries in general and failing states in particular. As we have just seen in Table 11, in our core CPIA regession (though in that alone) on our full sample of developing countries the direct effect of FREQUENCY remains significant. Now, on both our sub-samples, (columns (3) and (7)) it completely loses significance. The interaction terms themselves are not significant either in these two regressions, so not too much can be made of them. However, we may conclude weakly that in these societies there is little basis for believing that elections are structurally effective in disciplining governments into good policies regardless of their conduct. 
Table 12. Estimation on failing states and low income countries

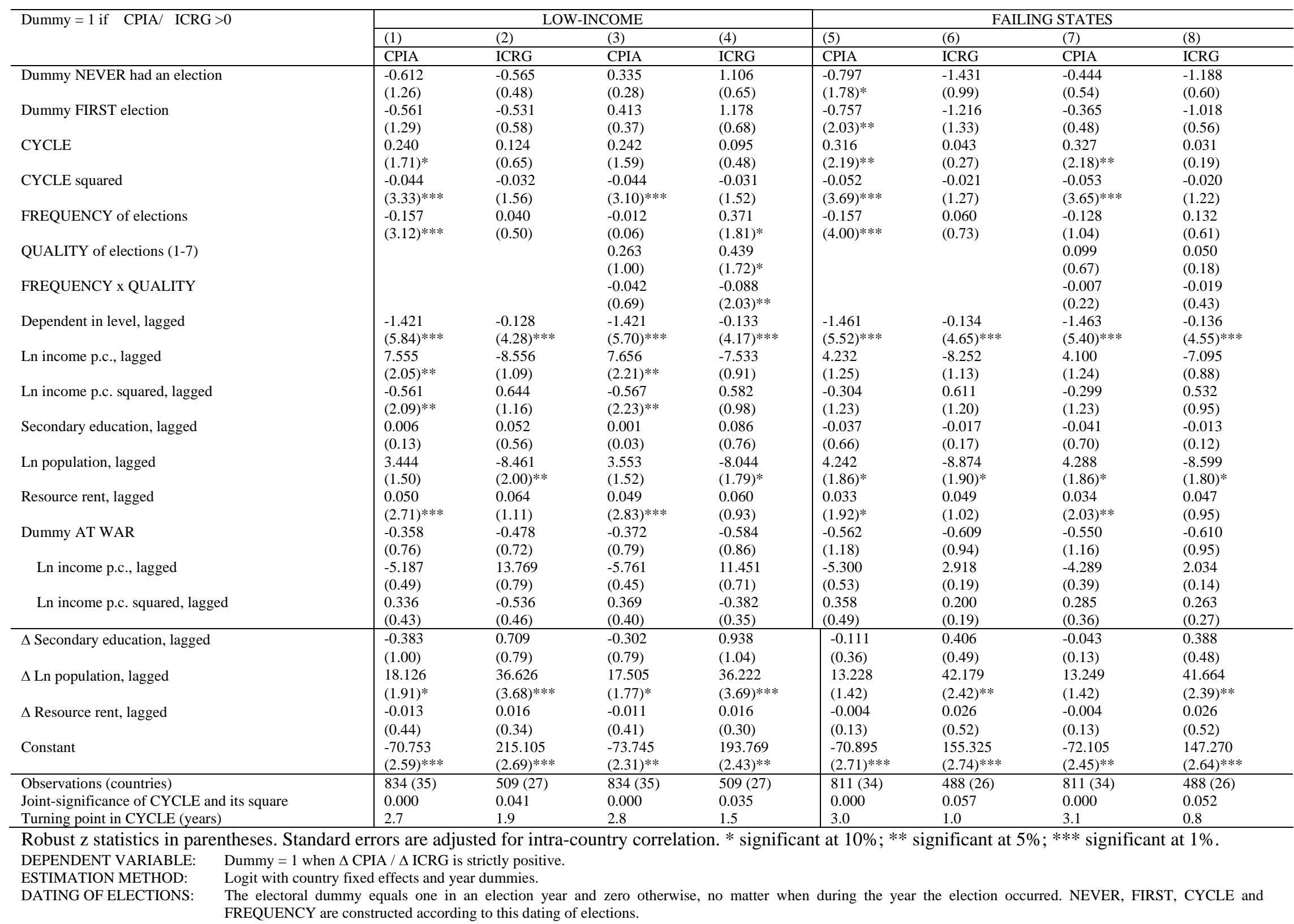




\section{IMPLICATIONS AND CONCLUSIONS}

Economic policy is critical for prosperity and so how it is shaped is of enormous importance for developing societies. It is now widely accepted that the struggle for good economic policies and governance is predominantly an internal process within these societies rather than something that can be imposed from outside by means of policy conditionality.

Since the fall of the Soviet Union both pressure from the international community and internal pressures within these societies have promoted elections. This first wave of change is now largely complete: almost all societies have elections. Potentially, elections are the key institutional technology of democracy than enables citizens to hold governments to account. While the potential may seem self-evident, quantitative political science research has become rather sceptical of the efficacy of democracy in improving economic performance: the broad conclusion is that there is little if any overall relationship. This paper has revisited the relationship, focusing upon policy choices instead of economic performance, and on elections as events instead of generalized ratings of the extent to which the country is democratic. We have investigated whether elections have forced governments into policy improvement.

We have found that elections have two offsetting effects. Because they are offsetting, unless they are distinguished the results are liable to be confused. Indeed, we showed that with a naïve approach of introducing a dummy variable for elections into a regression, elections appear to have no effect: as with the political science literature, this key aspect of democracy washes over the process of policy setting without trace. We might note that it is probably only by focusing on developing countries that these two effects can be distinguished: in developed countries there is liable to be too little variation, especially over time.

However, once the two effects are separately distinguished, each is clear and robust. Elections in developing countries have cyclical effects on policy. The instinct of President Obasanjo of Nigeria that 'the last year would be politics' was quite consistent with our results: periods in the vicinity of elections are less propitious for policy improvement. How powerful is the cycle. In Figure 1 we show the probability of policy improvement year-by-year at the mean of other characteristics for an electoral cycle of six years. The probability increases from 0.37 in the year of the election to 0.44 during the mid-term. Hence, the effect is not large but worth bearing in mind: by choosing the right moment for change the probability of success is increased by around $20 \%$. In this sense, elections are bad news for policy improvement, but not very bad news.

More important that this cyclical effect is the structural effect of elections. They indeed produce accountability of government to citizens. The degree to which they do this depends upon their frequency: the more frequent the better. The net effect of higher frequency has to be computed while allowing for the implications of each frequency for the cyclical effects: a lower frequency reduces the adverse effect of an election year compared to the mid-terms. The net effect of different frequencies on the probability of policy improvement is shown in Figure 2. The effects are large: taking the extremes of the range, shifting from an election once a decade to an election each year would almost double the chance of policy improvement in the average year. Since our core results are robust whether they are done in levels or differences, this statement about policy improvement can be reformulated as one about the eventual level of policy: frequent elections produce better policy.

Does this mean that concerns about elections are unwarranted? Our extension of the analysis to allow for variations in the quality of the conduct of elections suggests that there is indeed a sound basis for concern. While the results are less robust, there is a reasonable basis for concluding that if elections are badly conducted they lose their structural efficacy for policy improvement. This is surely what would be expected. Where governments resort to illicit means of securing electoral victory, such as bribery, ballot fraud and voter intimidation, they are released from the discipline of adopting good policies in order to 
win votes. Indeed, in order to resort to such strategies they may well need to adopt bad policies. An election which is not 'free and fair' is a broken technology: it cannot be expected to hold governments accountable to citizens.

Hence, the overall conclusion from our analysis is that the frequency and conduct of elections matter. Of course, accountability to citizens can reasonably be viewed as a good in itself. However, our results suggest that it is also efficacious for economic policy and that elections are a key instrument in achieving accountability. Elections fail to achieve accountability if they are infrequent, and if they are misconducted.

For international policy to promote development the results have an important, if uncomfortable, implication. It is widely accepted that good economic policy is critical to successful development. In the past the main approaches to foster good policy have been donor policy conditionality and technical assistance for 'capacity-building' but neither of these has had much success. Our results suggest that the route to policy improvement is through accountability of governments to their citizens through proper elections. To the extent that this process has failed it is because governments have subverted the electoral process. Hence, the international community needs to use its influence to reinforce the regular holding of elections and ensure that they are conducted to high standards. The development discourse of the last decade, replete with expressions such as 'partnership', 'country-led', and 'clients', has critiqued the previous emphasis of the World Bank on good economic policies as measured by the CPIA as being incompatible with the preferences of these societies themselves: local preferences were being overridden. Yet when citizens are able to hold their governments to account, they appear to want a better CPIA. The task for the international community is thus to promote the effective accountability of government to citizen. For example, conditioning aid upon the proper conduct of regular elections appears, on the basis of our evidence, to be a reasonable use of aid for development.

Figure 1. Predicted probability of policy change when FREQUENCY is six years.

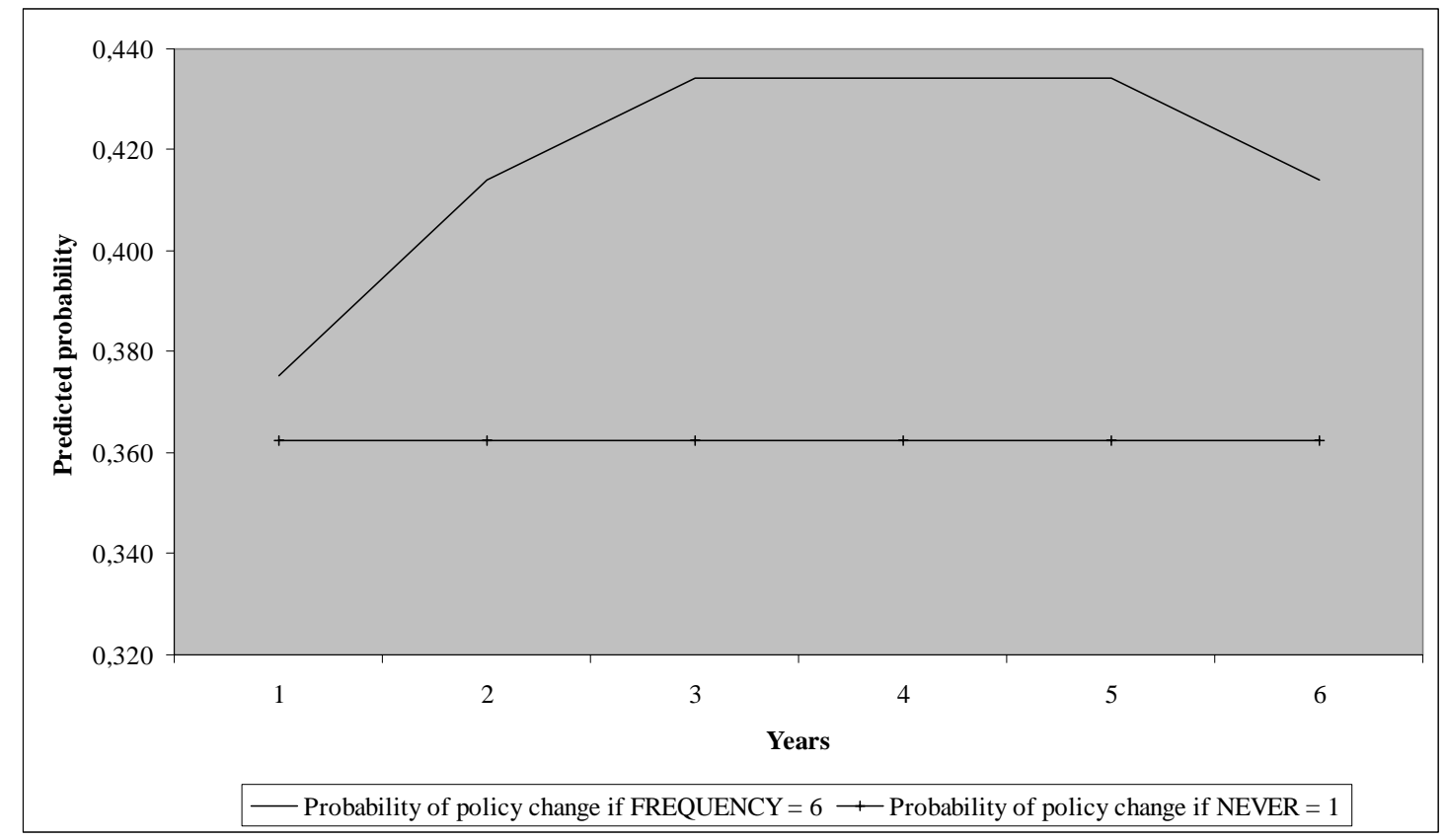


Figure 2. Predicted probability of policy change depending on FREQUENCY

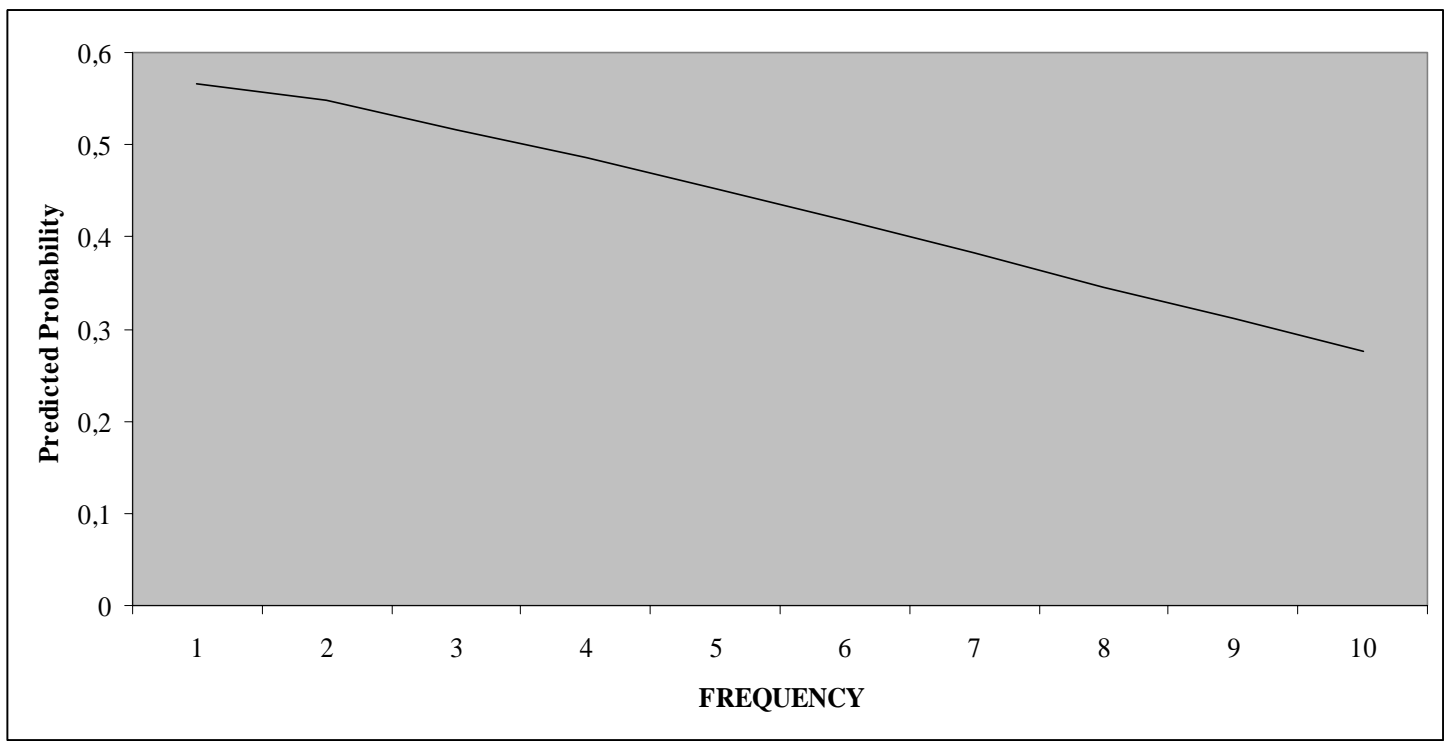




\section{REFERENCES}

Alesina A. and E. La Ferrara, 2005. Ethnic Diversity and Economic Performance. Journal of Economic Literature XLIII(3), 762-801.

Arellano M. and S. Bond, 1991. Some Tests of Specification for Panel Data: Monte Carlo Evidence and an Application to Employment Equations. Review of Economic Studies 58, 277-297.

Barro R.J. and J-W. Lee, 2000. International Data on Educational Attainment: Updates and Implications. CID Working Paper 42, Harvard University.

Besley T., 2006. Principled Agents? Princeton University Press.

Block S. A., 2002. Political Business Cycles, Democratization, and Economic Reform: the Case of Africa. Journal of Development Economics 67, 205-228.

Bossuroy T., 2007. Voting in an African Democracy: Does only Ethnicity Rule? EHESS, Paris School of Economics, DIAL, mimeo.

Brender A. and A. Drazen, 2005. Political Budget Cycles in New versus Established Democracies. Bank of Israel Discussion Paper 2005.04.

Collier, P., 2001. Implications of Ethnic Diversity. Economic Policy 16, 127-166.

Collier P. and A. Hoeffler, 2008. Testing the Neocon Agenda: Democracy in Resource-Rich Societies, European Economic Review.

Collier P. and D. Rohner, 2008. Democracy, Development and Conflict, Journal of the European Economic Association.

Collier P. and P. C. Vicente, 2008. Votes and Violence: Experimental Evidence from a Nigerian Election, Department of Economics, Oxford University, CSAE, mimeo.

Collier, P., 2009, Wars, Guns and Votes: Democracy in Dangerous Places, Random House, New York.

Dercon, S., M. Bratton, M. Kimenyi, R. Gutierrez-Romero and T. Bold (2008), Ethnicity and the 2007 Elections in Kenya, mimeo, Centre for the Study of African Economies, Oxford.

Drazen A. 2000. Political Economy in Macroeconomics. Princeton University Press.

Feng Y., 2003. Democracy, Governance and Economic Performance: Theory and Evidence. MIT Press.

Fridy K., 2007. The Elephant, Umbrella and Quarrelling Cocks: Disaggregating Partisanship in Ghana’s Fourth Republic. African Affairs 106, 423.

Beck T., Clarke G., Groff A., P. Keefer and P. Walsh, 2001. New Tools in Comparative Political Economy: The Database of Political Institutions. World Bank Economic Review 15(1), 165-176.

Judson R.A. and A.L. Owen, 1999. Estimating Dynamic Panel Data Models : A Guide for Macroeconomists. Economic Letters 65, 9-15.

Kudamatsu M., 2007, Has Democracy Reduced Infant Mortality in sub-Saharn Africa? LSE, mimeo. 
Nickell S., 1981. Biases in Dynamic Modems with Fixed Effects. Econometrica 49, 1417-1426.

Przeworski A, M.E. Alvarez, J.A. Cheibub, F. Limongi, 2000. Democracy and Development: Political Institutions and Wellbeing in the World, 1950-90. Cambridge University Press.

Tavares J. and R. Wacziarg, 2001. How Democracy Affects Growth. European Economic Review 45, 1341-1378.

Sevestre P. and A. Trognon, 1985. A Note on Autoregressive Error-Components Models. Journal of Econometrics 29, 231-245.

Singer J. D. and M. Small, 1994. Correlates of war project: International and civil war data, 1816-1992. Ann Arbor MI: Inter-University Consortium for Political and Social Research.

Shi M. and J. Svensson, 2006. Political Budget Cycles: Do They Differ Across Countries and Why? Journal of Public Economics 90, 1367-1389.

Small M. and J. D. Singer, 1982. Resort to Arms: International and Civil War, 1816-1980, Beverly Hills CA: Sage.

Vicente P., 2007. Is Vote-Buying Effective? Evidence from a Randomized Experiment in West Africa. Mimeo, CSAE, Oxford.

Wantcheckon L. 2003. Clientalism and Voting Behaviour: Evidence from a Field Experiment in Benin. World Politics 55, 399-422. 


\section{Appendix 1 - Definition of the Country Policy and Institutional Assessment (CPIA)}

A. Economic management

1. Management of inflation and macroeconomic imbalances

2. Fiscal policy

3. Management of external debt

4. Management and sustainability of the development program

B. Structural policies

1. Trade policy and foreign exchange regime

2. Financial stability and depth

3. Banking sector efficiency and resource mobilization

4. Competitive environment for the private sector

5. Factor and product markets

6. Policies and institutions for environmental sustainability

C. Policies for social inclusion / equity

1. Gender

2. Equity of public resource use

3. Building human resources

4. Social protection and labor

5. Monitoring and analysis of poverty outcomes and impacts

D. Public sector management and institutions

1. Property rights and rule-based governance

2. Quality of budgetary and financial management

3. Efficiency of revenue mobilization

4. Quality of public administration

5. Transparency, accountability and corruption in the public sector

Each of the twenty components of the CPIA is rated on a scale of 1-6. 


\section{Appendix 2. Presentation of the data}

\section{CPIA}

Country Policy and Institutional Assessment (World Bank). See Appendix 1.

\section{ICRG}

Composite indicator of political stability, economic stability and financial stability. It is rated from 0 (bad policy and institutions) to 100 (good policy and institutions). Source: International Country risk Guide, Political Risk Services. http://www.prsgroup.com/

\section{Income per capita}

Real gross domestic product per capita (\$ in 1996 constant prices), Penn World Tables 6.1. http://pwt.econ.upenn.edu/

\section{Population}

World Development Indicators of the World Bank (2005).

\section{Secondary education}

Barro R. and J.W. Lee (2000) dataset. Percentage of the population who completed secondary education (population aged 25 and above).

http://www.cid.harvard.edu/ciddata/ciddata.html

\section{Resource Rents}

Natural resource rents (\% of GDP). Resource Rents are calculated by summing the total value of rents for all extractive (i.e. non agricultural) resources. These values are in current US\$ and are then divided by GDP in current US\$. Source: Collier and Hoeffler (2005).

\section{Dummy at war}

Dummy equals one during civil war. Correlates of War (Singer and Small, 1994 ; Small and Singer, 1982). Hhttp://www.correlatesofwar.org/H. It is updated using the PRIO database (www.prio.no/CSCW/Datasets/Armed-Conflict/)

\section{Elections}

Database of Political Institutions (Beck et al., 2001) of the World Bank. http://econ.worldbank.org/WBSITE/EXTERNAL/EXTDEC/EXTRESEARCH/0,,contentMDK:20649465 pagePK:64214825 piPK:64214943 theSitePK:469382,00.html

We use executive elections for presidential systems and legislative elections for parliamentary systems.

FREQUENCY: the number of years between election in year $t$ and the previous election. This number is reported for each year of the mandate.

CYCLE: the number of years that separate year $t$ from the nearest election, whether this is the previous election or the next election.

NEVER: dummy which is equal to one if the country never had an election. 
FIRST: dummy which is equal to one during the first mandate.

QUALITY: quality of previous election. It is constructed using the EIEC and LIEC variables of the DPI database (respectively Executive and Legislative Indices of Electoral Competitiveness). It takes the values: 1: No legislature; 2: Unelected legislature; 3: Elected, 1 candidate; 4: 1 party, multiple candidates; 5: multiple parties are legal but only one party won seats; 6 : multiple parties did win seats but the largest party received more than $75 \%$ of the seats; 7 : largest party got less than $75 \%$. If, for example, elections occur in years $t$ and $t+4$, we report the value of EIEC/LIEC in $t$ (depending on whether the political system is presidential or parliamentary) during the whole duration of the mandate starting in $t+4$.

We also use the database on elections used by Brender and Drazen (2005). http://www.econ.umd.edu/ drazen/ 


\section{Appendix 3. Sample}

\begin{tabular}{|c|c|c|}
\hline Developing countries in the main sample & Using ICRG data & Using DRAZEN data \\
\hline \multirow{4}{*}{$\begin{array}{r}\text { Algeria } \\
\text { Argentina } \\
\text { Barbados } \\
\text { Belize }\end{array}$} & $\mathrm{x}$ & \\
\hline & $\mathrm{x}$ & $\mathrm{X}$ \\
\hline & & \\
\hline & & \\
\hline Bolivia & $\mathrm{X}$ & $\mathrm{x}$ \\
\hline Botswana & $\mathrm{x}$ & \\
\hline Brazil & $\mathrm{x}$ & $\mathrm{x}$ \\
\hline Bulgaria & $\mathrm{x}$ & $\mathrm{x}$ \\
\hline Chile & $\mathrm{x}$ & $\mathrm{x}$ \\
\hline China & $\mathrm{x}$ & \\
\hline Colombia & $\mathrm{x}$ & $\mathrm{x}$ \\
\hline Costa Rica & $\mathrm{X}$ & $\mathrm{X}$ \\
\hline Croatia & $\mathrm{x}$ & \\
\hline Czech Republic & $\mathrm{x}$ & $\mathrm{x}$ \\
\hline Dominican Rep. & $\mathrm{x}$ & $\mathrm{x}$ \\
\hline Ecuador & $\mathrm{x}$ & $\mathrm{x}$ \\
\hline El Salvador & $\mathrm{x}$ & $\mathrm{x}$ \\
\hline Fiji & & $\mathrm{x}$ \\
\hline Guatemala & $\mathrm{x}$ & $\mathrm{x}$ \\
\hline Hungary & $\mathrm{x}$ & $\mathrm{x}$ \\
\hline India & $\mathrm{x}$ & $\mathrm{x}$ \\
\hline Jamaica & $\mathrm{x}$ & \\
\hline Jordania & $\mathrm{x}$ & \\
\hline Kenya & $\mathrm{x}$ & \\
\hline Korea & $\mathrm{x}$ & $\mathrm{x}$ \\
\hline Malawi & $\mathrm{x}$ & \\
\hline Malaysia & $\mathrm{x}$ & $\mathrm{x}$ \\
\hline Mauritius & & $\mathrm{x}$ \\
\hline Mexico & $\mathrm{x}$ & $\mathrm{x}$ \\
\hline Panama & $\mathrm{x}$ & $\mathrm{x}$ \\
\hline Paraguay & $\mathrm{x}$ & $\mathrm{x}$ \\
\hline Peru & $\mathrm{x}$ & $\mathrm{x}$ \\
\hline Philippines & $\mathrm{x}$ & $\mathrm{x}$ \\
\hline Poland & $\mathrm{x}$ & $\mathrm{x}$ \\
\hline Romania & $\mathrm{x}$ & $\mathrm{x}$ \\
\hline Russia & $\mathrm{x}$ & $\mathrm{x}$ \\
\hline Slovakia & $\mathrm{x}$ & $\mathrm{x}$ \\
\hline South Africa & $\mathrm{x}$ & $\mathrm{x}$ \\
\hline St. Lucia & & \\
\hline Swaziland & & \\
\hline Syria & $\mathrm{x}$ & \\
\hline Thailand & $\mathrm{x}$ & \\
\hline Trinidad and Tobago & $\mathrm{x}$ & $\mathrm{x}$ \\
\hline Tunisia & $\mathrm{x}$ & \\
\hline Turkey & $\mathrm{x}$ & $\mathrm{x}$ \\
\hline Uruguay & $\mathrm{X}$ & $\mathrm{x}$ \\
\hline Venezuela & $\mathrm{x}$ & $\mathrm{x}$ \\
\hline Western Samoa & & \\
\hline & Bahrain & \\
\hline & Iran & \\
\hline & Iraq & \\
\hline
\end{tabular}


Appendix 3. continued.

\begin{tabular}{|c|c|c|}
\hline Failing States in the main sample & Using ICRG data & Using DRAZEN data \\
\hline Bangladesh & $\mathrm{x}$ & \\
\hline Benin & & \\
\hline Burundi & & \\
\hline Cameroon & $\mathrm{x}$ & \\
\hline Central African Rep & & \\
\hline Congo, Rep & $\mathrm{x}$ & \\
\hline Democratic Rep. Of Congo & $\mathrm{x}$ & \\
\hline Egypt & $\mathrm{x}$ & \\
\hline Ethiopia & $\mathrm{x}$ & \\
\hline Gambia & $\mathrm{x}$ & \\
\hline Ghana & $\mathrm{x}$ & \\
\hline Haiti & $\mathrm{x}$ & \\
\hline Honduras & $\mathrm{x}$ & $\mathrm{x}$ \\
\hline Indonesia & $\mathrm{x}$ & \\
\hline Lesotho & & \\
\hline Liberia & $\mathrm{x}$ & \\
\hline Mali & $\mathrm{x}$ & $\mathrm{x}$ \\
\hline Mauritania & & \\
\hline Mozambique & $\mathrm{x}$ & \\
\hline Nepal & & $\mathrm{x}$ \\
\hline Nicaragua & $\mathrm{x}$ & $\mathrm{x}$ \\
\hline Niger & $\mathrm{x}$ & \\
\hline Papua New Guinea & $\mathrm{x}$ & $\mathrm{x}$ \\
\hline Pakistan & $\mathrm{x}$ & $\mathrm{x}$ \\
\hline Rwanda & & \\
\hline Senegal & $\mathrm{x}$ & \\
\hline Sierra Leone & $\mathrm{x}$ & \\
\hline Sri Lanka & $\mathrm{x}$ & $\mathrm{x}$ \\
\hline Sudan & $\mathrm{x}$ & \\
\hline Togo & $\mathrm{x}$ & \\
\hline Uganda & $\mathrm{x}$ & \\
\hline Vietnam & & \\
\hline Zambia & $\mathrm{x}$ & \\
\hline Zimbabwe & $\mathrm{x}$ & \\
\hline
\end{tabular}

